\title{
Chickpea molecular breeding: New tools and concepts
}

Teresa Millan ${ }^{1, *}$, Heather J. Clarke ${ }^{2}$, Kadambot H. M. Siddique ${ }^{2}$, Hutokshi K. Buhariwalla ${ }^{3}$, Pooran M. Gaur ${ }^{3}$, Jagdish Kumar ${ }^{3,4}$, Juan Gil ${ }^{1}$, Guenter Kahl ${ }^{5,6}$ \& Peter Winter ${ }^{5,6}$

${ }^{1}$ Dpto Genética, Univ. de Córdoba, Campus Rabanales, Edificio Mendel C5, 14017 Córdoba, Spain; ${ }^{2}$ Centre for Legumes in Mediterranean Agriculture, Faculty of Natural and Agricultural Sciences, The University of Western Australia, 35 Stirling Highway, Crawley, WA 6009, Australia; ${ }^{3}$ International Crops Research Institute for the SemiArid Tropics (ICRISAT), Patancheru, Andhra Pradesh 502 324, India; ${ }^{4}$ Beans-for-Health Research Foundation, 11791 Sandy Row, Inkerman (Near Ottawa), Ontario, Canada K0E 1JO; ${ }^{5}$ Plant Molecular Biology, University of Frankfurt, Frankfurt Innovation Centre Biotechnology, Altenhöferallee 3, D-60438 Frankfurt, Germany; ${ }^{6}$ GenXPro, Frankfurt Innovation Centre Biotechnology, Altenhöferallee 3, D-60438 Frankfurt, Germany

(*author for correspondence: e-mail: gelmivat@uco.es)

Received 15 December 2004; accepted 18 October 2005

Key words: chickpea breeding, functional genomics, genetic map, pathogen resistance, stress tolerance

\begin{abstract}
Summary
Chickpea is a cool season grain legume of exceptionally high nutritive value and most versatile food use. It is mostly grown under rain fed conditions in arid and semi-arid areas around the world. Despite growing demand and high yield potential, chickpea yield is unstable and productivity is stagnant at unacceptably low levels. Major yield increases could be achieved by development and use of cultivars that resist/tolerate abiotic and biotic stresses. In recent years the wide use of early maturing cultivars that escape drought stress led to significant increases in chickpea productivity. In the Mediterranean region, yield could be increased by shifting the sowing date from spring to winter. However, this is hampered by the sensitivity of the crop to low temperatures and the fungal pathogen Ascochyta rabiei. Drought, pod borer (Helicoverpa spp.) and the fungus Fusarium oxysporum additionally reduce harvests there and in other parts of the world. Tolerance to rising salinity will be a future advantage in many regions. Therefore, chickpea breeding focuses on increasing yield by pyramiding genes for resistance/tolerance to the fungi, to pod borer, salinity, cold and drought into elite germplasm. Progress in breeding necessitates a better understanding of the genetics underlying these traits. Marker-assisted selection (MAS) would allow a better targeting of the desired genes. Genetic mapping in chickpea, for a long time hampered by the little variability in chickpea's genome, is today facilitated by highly polymorphic, co-dominant microsatellite-based markers. Their application for the genetic mapping of traits led to inter-laboratory comparable maps. This paper reviews the current situation of chickpea genome mapping, tagging of genes for ascochyta blight, fusarium wilt resistance and other traits, and requirements for MAS. Conventional breeding strategies to tolerate/avoid drought and chilling effects at flowering time, essential for changing from spring to winter sowing, are described. Recent approaches and future prospects for functional genomics of chickpea are discussed.
\end{abstract}

\section{Chickpea: A valuable grain legume}

Chickpea (Cicer arietinum L.) is the only cultivated species within the genus Cicer. The crop is a selfpollinated diploid $(2 n=2 x=16)$ with a relatively small genome $(740 \mathrm{Mb}$, Arumuganathan \& Earle,
1991). It is cultivated in arid and semi-arid areas around the world. With over 10 million ha under cultivation, chickpea is second only to common bean (Phaseolus vulgaris) and third in production among the legumes. The major producers India, Pakistan and Turkey contribute $65 \%, 9.5 \%$ and $6.7 \%$ respectively, 
to the world harvest (FAOSTAT, 2005). Despite its high morphological variability, genetic variation is low, probably a consequence of its monophyletic descendence from its wild progenitor $C$. reticulatum in the Fertile Crescent (Ladizinsky \& Adler, 1976; Lev-Yadun et al., 2000; Abbo et al., 2003). Chickpea seeds contain 20-30\% protein, approximately $40 \%$ carbohydrates, and only 3-6\% oil (Gil et al., 1996); and moreover, they are a good source of calcium, magnesium, potassium, phosphorus, iron, zinc and manganese (Ibrikci et al., 2003). Chickpeas do not contain as high amounts of isoflavones as soybeans do (USDA-ARS, 2004), but provide more beneficial carotenoids such as $\beta$-carotene than genetically engineered "Golden Rice". Compared to other grain legumes, anti-nutritive components are nearly absent (Williams \& Singh, 1987). Thus, chickpea is considered a functional food or nutraceutical (Agharkar, 1991; McIntosh \& Topping, 2000; Charles et al., 2002). While it is a cheap source of protein and energy in the developing world, it is also an important food to the affluent populations to alleviate major food-related health problems. However, more research is necessary to elucidate and extend the food and nutraceutical benefit of this important food legume through breeding.

Commercially, the species is grouped into desi and kabuli types: desi chickpeas generally have small, coloured seeds, whereas kabulis produce large, creamcoloured ones. To a certain extent this classification overlaps with the macrosperma and microsperma races proposed by Moreno and Cubero (1978). Classification also reflects utilisation: whereas kabulis are usually utilised as whole grains, desis are decorticated and processed into flour. Differing also in other agronomic characteristics, kabuli chickpeas probably evolved in the Mediterranean basin from desi type (Moreno \& Cubero, 1978; Gil \& Cubero, 1993; Jana \& Singh, 1993). Kabuli $\times$ desi crosses are used in many breeding programs to combine genes for cold tolerance, resistance to ascochyta blight and long vegetative growth more frequently found in kabuli types, with genes for heat and drought tolerance, resistance to fusarium wilt and early flowering prevalent in desi types (Singh, 1987).

Currently, productivity of chickpea is very low (world average $\sim 0.8$ t/ha, FAOSTAT, 2005) and has stagnated in recent years. Reasons for only marginal improvements are a series of biotic and abiotic stresses that reduce yield and yield stability. Especially ascochyta blight and fusarium wilt, pod borer, drought and cold are major constraints to yield improvement and adoption of the crop by farmers. Therefore, improving resistance to biotic and tolerance to abiotic stresses as well as a general increase in dry matter are major aims of chickpea breeders around the world. Recent years have seen tremendous progress in the development of novel genetic tools such as DNA molecular markers, dense genetic maps, and whole-genome transcription profiling techniques to identify genomic regions and genes underlying plant stress responses. Although fully applied only to a few model species, these new technologies are dramatically improving our understanding of basic principles of plant metabolism in general. Now, it is up to researchers and breeders to capitalise on these new opportunities to improve and stabilise chickpea yield for the benefit of farmers and consumers. The aim of this review is to provide an update on progress in the development and application of molecular breeding approaches to the improvement of chickpea's resistance to biotic and abiotic stresses.

\section{Genome mapping in chickpea: Merging maps is a major prerequisite for molecular breeding}

Knowledge of the inheritance of agronomic characters is a basic requirement to identify and integrate interesting genes in linkage maps and to utilise these maps for marker-assisted selection (MAS) of these characters to accelerate the development of new cultivars. In chickpea, genetics of resistance to ascochyta blight (Singh \& Reddy, 1983; Tewari \& Pandey, 1986; Dey \& Singh, 1993; Tekeoglu et al., 2000a), fusarium wilt (Muehlbauer \& Singh, 1987; Gumber et al., 1995; Kumar, 1998; Tullu et al., 1998; Tekeoglu et al., 2000b; Rubio et al., 2003), chilling tolerance at flowering (Clarke \& Siddique, 2003), and flowering time (Or et al., 1999) have been extensively analysed. A comprehensive overview of previous genetic mapping efforts in chickpea covering the period until 2001 is available (Winter et al., 2003) and thus, we will focus only on new developments here. Most chickpea geneticists agree that the generation of an integrated genetic map of the crop, comprising loci of both economic and scientific importance, presently is a central goal of chickpea genetics. Until recently, the low level of polymorphism in the chickpea genome and the scarcity of co-dominant DNA-based markers were serious constraints to achieving this goal. The advent of sequencetagged microsatellite sites (STMS) markers (Hüttel et al., 1999; Winter et al., 1999), however, provided the opportunity to integrate the different available maps. 
Here, we summarise some of the progress achieved using these markers. In recent years, STMS markers were indeed applied for the generation of almost all published genetic maps of chickpea developed employing populations from crosses between $C$. arietinum and C. reticulatum (Tekeoglu et al., 2002; Benko-Iseppon et al., 2003; Rakshit et al., 2003; Pfaff \& Kahl, 2003; Abbo et al., 2005), C. arietinum $\times C$. echinospermum (Collard et al., 2003) and intraspecific populations (Cho et al., 2002; Flandez-Galvez et al., 2003a, 2003b; Udupa \& Baum, 2003; Cho et al., 2004; Sharma et al., 2004; Cobos et al., 2005). Nevertheless, most genomic regions harbouring genes for important traits are not yet sufficiently saturated with co-dominant markers to apply MAS in plant breeding programs.

Genetic mapping mostly focussed on tagging agronomically relevant genes such as ascochyta (Tekeoglu et al., 2002; Udupa \& Baum, 2003; Collard et al., 2003; Flandez-Galvez et al., 2003a; Cho et al., 2004) and fusarium resistance genes (Benko-Iseppon et al., 2003; Sharma et al., 2004), and yield-influencing characters such as double podding and other morphological characters (Cho et al., 2002; Rajesh et al., 2002). Most of the authors compared their maps to the most extended genetic map of chickpea (Winter et al., 2000). Though this map, which currently comprises more than 470 markers, was based on an interspecific cross between the cultigen and a $C$. reticulatum accession, linkages of STMS markers is consistent with most other maps, irrespective of whether they were generated for an inter- or intraspecific population. However, distances between the markers differed considerably in some cases (Tekeoglu et al., 2002; Collard et al., 2003; Cho et al., 2004; Cobos et al., 2005). Contrary to the results obtained with STMS markers, Collard et al. (2003) could not detect similarities between the order of RAPD and ISSR markers in their map as compared to previous studies. The emerging body of data now allows us to draw three conclusions: (i) STMS markers are indeed elite anchor markers for merging genetic maps in chickpea, (ii) dominant markers are transferable between populations only in rare cases, and their identity needs to be confirmed by either linkages to other markers co-segregating in at least two populations, or sequencing and conversion into e.g. a sequence characterised amplified region (SCAR) marker, (iii) the map of Winter et al. (2000) together with its amendments developed on the same population may be employed as a reference map for genetic mapping in chickpea and comparative mapping between chickpea and other legumes, at least until a comprehen- sive integrated map becomes available. A current map integrating much of the information available in the literature is presented in Figure 1.

\section{The step from genetic to physical mapping}

One of the logical spin-offs of a genetic map, the construction of a complete physical map of a genome, still represents a challenge for chickpea genomics. However, a physical map is fundamental to any progress towards a more complete understanding of the structure, composition and function of the genome. This cannot be achieved by mere recombination mapping. More so, the isolation of genes of agronomic importance (e.g. genes encoding receptor kinases, proteins of signal transmission, transcription factors, regulatory proteins or small regulatory RNAs, or enzymes of defence pathways) inevitably necessitates a physical map. In essence, the era of physical mapping in chickpea is beginning now. It will, and has to be succeeded by an era of DNA sequence analysis. And the first steps towards this goal have already been made: at least four bacterial artificial chromosome (BAC) libraries are available, but definitely under-used, and a cytogenetic map of the chickpea chromosomes is close to completion.

One of the BAC libraries has been described in detail (Rajesh et al., 2004). A second one, derived from the fusarium-resistant chickpea cultivar (ICC 4958) was established in the binary vector V41 with a $5 \times$ coverage of the genome. The library has been spotted onto high-density nylon filters (close to 14,000 clones/filter) and used for hybridisation experiments. These experiments clearly proved, that some markers, that were located on the integrated genetic map (Winter et al., 2000; Benko-Iseppon et al., 2003), and later on sequenced, are either low-copy (e.g. the thaumatin [PRP5]-encoding gene), middle-repetitive (e.g. the gene encoding $N$-hydroxycinnamoyl-benzoyl transferase, a protein catalysing a particular step in the phytoalexin synthesis pathway), or highly repetitive (marker CS 27, a Ty3-gypsy-like LTR retrotransposable element CaRep; Staginnus et al., 1999, 2001). Also, a series of 141 resistance gene analogues (RGAs) have been identified in this BAC library. Clustering of the various R-genes was neither observed in the BACs nor suggested by genetic mapping of RGAs (Hüttel et al., 2002). Recently, Lichtenzveig et al. (2005) also constructed a BAC and a BIBAC library for chickpea; the two libraries contain a total of 38,016 clones and are 

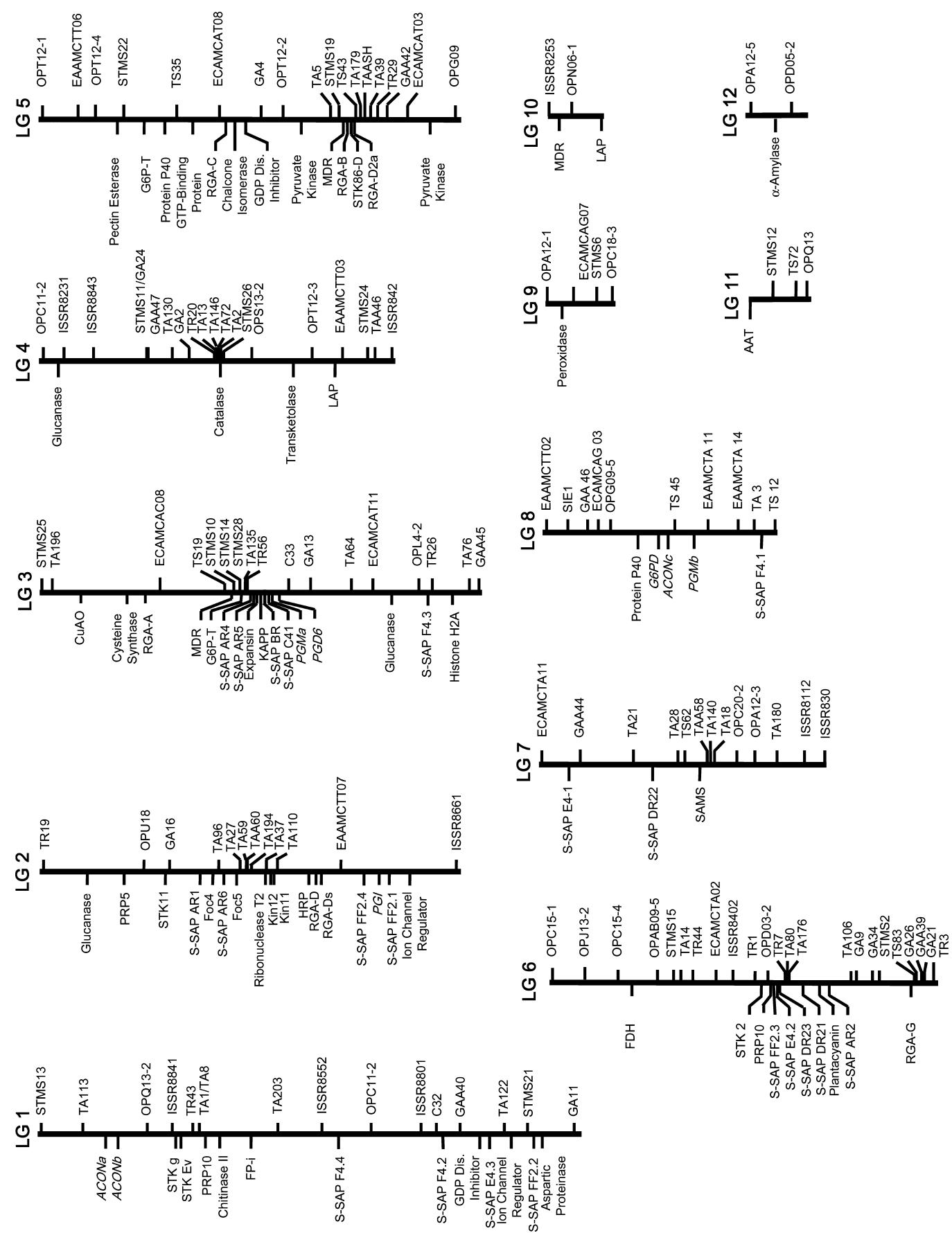

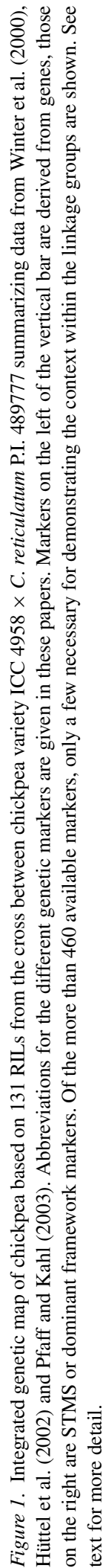


equivalent to ca. $7.0 \times$ genomes of chickpea. Thus, the available BAC libraries could be employed for the generation of a physical map and as potential resources for whole genome sequencing, which should be a future perspective in chickpea genomics.

An alternative route to physical mapping has already started in collaboration between the laboratory of J. Dolezel (Olomouc, Czech Republic) and the University of Frankfurt with the aim to bridge the gap between the recombination-based genetic map and the chromosome-based map. The chromosomes were isolated from root tip cells synchronised for their mitosis, separated by fluorescent cell sorting and identified by their size. As a proof of principle the localization of 5S-rDNA on chromosomes 2 (B) and 7 (G), that had already been shown by fluorescent in situ hybridizations (Gortner et al., 1998; Staginnus et al., 1999) was confirmed. Moreover, the smallest LG 8, identified by the STMS GAA46, corresponds to the smallest chromosome $8(\mathrm{H})$. None of the other chromosome fractions contain the sequence of this marker (Vlácilová et al., 2002).

Exploiting this technology, linkage group (LG) 1 has already been identified as chromosome $\mathrm{F}$ (or G), LG 2 as chromosome F (or G), LG 3 as chromosome C (or D), LG 4 as chromosome B, LG 5 as chromosome $\mathrm{C}$ (or D), LG 6 as chromosome E, LG 7 as chromosome A, and LG 8 as chromosome H, respectively. At present, the separation is brought to perfection, and packages of at least 10 different linkage-group-specific markers address the precise identification of linkage groupchromosome relationships. The resulting map then will allow the identification of the most interesting chromosomes carrying a particular trait (or gene), opening an avenue for the isolation and characterisation of the underlying sequence, its transcription and regulation, and mechanism of action of the encoded protein. These features are still missing in all chickpea research, but they are badly needed for an understanding of basic plant properties as, for example, yield, resistances towards abiotic and biotic stresses, growth and development, and seed quality, to name only few.

\section{Breeding for resistance to biotic stresses}

In the Mediterranean region, chickpea is traditionally sown in spring and, as a consequence of the low rainfall during the growth period in dry summers, this results in poor biomass development. Winter sowing expands the vegetative growth period and improves the seed yield up to $2 \mathrm{t} / \mathrm{ha}$ (Singh \& Reddy, 1996; Singh et al., 1997), but is rarely adopted by the farmers because the cool and wet weather, typical for Mediterranean winters, favours the development of ascochyta blight. Blight, caused by the necrotrophic fungus Ascochyta rabiei (Pass.) Lab., affects all aerial parts of the plant. It is also a problem in North America, Pakistan, Northwest India and Australia. Sources of resistance have been identified (Singh \& Reddy, 1983) and the development of stable blight-resistant lines would allow a shift to sowing into the rainy season. Since this is currently not the case, winter planting is yet illusory (Halila et al., 2000). More durable resistance could probably be achieved by pyramiding of resistance genes via MAS and is a major challenge for chickpea breeders.

The second most important fungal disease and another major constraint for increasing chickpea yield is fusarium wilt, caused by Fusarium oxysporum f. sp. ciceris (Nene \& Reddy, 1987). Many traditional Mediterranean kabuli cultivars are susceptible to the soil-borne disease, and sources of resistance (mainly desi cultivars) were included in breeding programs (Singh, 1987; Kaiser et al., 1994). However, development of resistant cultivars is hindered by the pathogenic variability of the fungus. To date, eight pathogenic races of Fusarium, discriminated on the basis of reactions they evoke in a differential set of cultivars, have been reported (Haware \& Nene, 1982; Jiménez-Díaz et al., 1993).

Other diseases and pests have been reported (reviews by Nene \& Reddy, 1987; Greco, 1987; Reed et al., 1987; Singh et al., 1994), but seem to be a serious problem only in certain regions of the world. One of the most problematic pests in India and Australia is the pod borer, Helicoverpa armigera. Some resistance against this pest has been found in wild Cicer species (Patankar et al., 1999; Sharma et al., 2005). Botrytis grey mould can become problematic under conditions favouring overgrowth and dense crop canopy (Kaiser et al., 2000), and root rots caused by Sclerotium, Pythium spp. and Phytophthora are important in the sub-tropics and tropics (Kraft et al., 2000; Knights \& Siddique, 2002). Rust of chickpea, caused by Uromices-ciceris-arietini, can be a problem in cool and moist weather. It may appear almost simultaneously with ascohyta blight (Nene \& Reddy, 1987), and especially occurs at high altitudes as e.g. in Central Mexico (Díaz-Franco \& Pérez-García, 1995; Haware, 1998). Only moderate levels of incomplete and partial resistance against rust are available (Rubiales et al., 2001). Wide-spread application of winter sowing under Mediterranean conditions may also result in outbreaks of broomrape (Orobanche 
crenata) (Rubiales et al., 1999). Although high levels of resistance are found in chickpea germplasm which can be exploited for resistance breeding (Singh, 1987; Rubiales et al., 2003), the spread of winter sowing may be counteracted by the evolution of new and more aggressive broomrape pathotypes. Though sources of resistances or tolerances to pests and minor diseases have been recently identified (Prajapati et al., 2003; Rubiales et al., 2003; Ansari et al., 2004; Pande et al., 2004), in most cases genetic studies or segregating populations for genetic mapping studies are not available.

\section{Mapping QTL for resistance to Ascochyta rabiei: Current status}

The genetics of resistance to ascochyta blight has been extensively analysed because the disease is of great agronomic and economic importance. However, the emerging picture is confusing: depending on the fungal isolate and the cultivar, either one dominant, one recessive and one dominant, or one recessive resistance gene was reported. Also, two complementary recessive, or two complementary dominant genes were detected. At present, it is not clear whether the reported resistance genes represent the same or different loci because allelic tests were not performed (for a recent review see Winter et al., 2003). To complicate the picture even more, other genes may modify the expression of resistance. Another drawback for mapping of ascochyta resistance genes in the field is that, in many chickpea growing regions, several patho- and genotypes of the fungus may coexist in the same field or even in the same lesion (Morjane et al., 1994; Jamil et al., 2001; Peever et al., 2004). Since random mating may occur between different pathotypes of the fungus carrying different mating type alleles (Barve et al., 2003), genetic recombination may contribute to genotypic diversity and provide the fungus with an additional means to adapt to newly introduced resistant germplasm (Peever et al., 2004).

Different methods are applied for assessment of disease severity. Testing under controlled glasshouse or growth chamber conditions (Singh et al., 1992; Udupa \& Baum, 2003) combined with field screening (Flandez-Galvez et al., 2003a; Millán et al., 2003; Cho et al., 2004) would very much help to improve the reproducibility of the results, since severity and spread of the disease are highly dependent on environmental conditions and especially on humidity (which may change from year to year). Indeed, Cho et al.
(2004) observed dramatic increases in severity of blight symptoms, if $100 \%$ relative humidity was maintained for more than 2 days after inoculation, as compared to normal greenhouse conditions. Further, different loci may contribute to resistance at different points of the life cycle of the plant (Collard et al., 2003). As the scale used for disease evaluation to blight (1-9 scale; Singh et al., 1981; Reddy \& Singh, 1984) is subjective particularly for intermediate values, a bias may be introduced by the researcher that may also affect the accuracy of tagging blight-resistant genes with markers. In fact, some authors detected different QTLs measuring disease reaction in the same environment using two disease scoring systems (Flandez-Galvez et al., 2003a).

To improve the reliability of mapping QTLs for ascochyta blight resistance, recombinant inbred lines (RILs) were used as mapping populations and rated in subsequent years. For example, Tekeoglu et al. (2000a) employed three different RIL populations and tested them in the field for two growing seasons against the A. rabiei pathotype prevalent in the United States. This study defined two major recessive and complementing resistance genes together with several modifiers. A third gene could only be detected in 1 year. Absence of either one of the two major genes led to susceptibility, whereas the modifiers determined the degree of resistance (Tekeoglu et al., 2000a). Two QTLs (QTL-1 and QTL-2) were identified in one of these populations and together accounted for $50.3 \%$ and $45.0 \%$, respectively, of the estimated phenotypic variation in two subsequent years. Interval mapping located the QTLs with high LOD scores on LGs 6 and 1 of the maps of Gaur and Slinkard (1990) and Kazan et al. (1993), respectively. Two RAPD markers (UBC733b and UBC181a) flanked QTL-1, whereas QTL-2 was located between an ISSR and an isozyme marker $5.9 \mathrm{cM}$ apart (Santra et al., 2000). Rakshit et al. (2003) used the population and ascochyta blight data set from the Pullman group (Tekeoglu et al., 2000; Santra et al., 2000) to identify two DNA amplification fingerprinting (DAF, Caetano-Anollés et al., 1991) markers, OPS06-1 and OPS03-1, in close vicinity of markers UBC733b and UBC181a flanking QTL-1. Marker OPS06-1 was located between UBC733b and UBC181a, and is probably the most closely linked marker for QTL-1 available to date. Another, more loosely coupled marker, OPS03-1, could be transferred to the population on which the map of Winter et al. (2000) was based. There, it mapped to LG 4, thus identifying this LG as LG 6 of Gaur and Slinkard (1990) and Kazan et al. (1993). 
STMS markers mapped on LG 4 were transferred to the population segregating for ascochyta resistance, locating QTL-1 to the interval STMS 11, GAA47, GA2 and TR20. Twelve out of 14 STMS markers could be used in both populations. The study by Rakshit et al. (2003) showed that dominant markers can be transferred to other populations and located on the reference map of chickpea via closely linked STMS markers. Another study by Tekeoglu et al. (2002) confirmed the QTL reported by Santra et al. (2000) and, through the use of STMS markers (Hüttel et al., 1999; Winter et al., 1999) located QTL-1 on their LG 8 close to STMS GAA47 and QTL 2 on LG 4 (indicative markers TA72 and GA2).

A QTL was also detected in a genomic region saturated with RAPD markers using ILC3279 as source of resistance in an intraspecific cross (Millán et al., 2003). Recently, SCAR markers tightly linked to this QTL have been developed (Iruela et al., 2006), and STMS analysis revealed that this QTL could be the same as QTL-2 of Santra et al. (2000), since it was linked to the same markers TA72 and TA146.

Rating for ascochyta resistance in all these studies was performed in the field using natural inoculum without control over the fungal pathotypes or the environment. Udupa and Baum (2003) were the first to employ defined A. rabiei pathotypes (I and II) in a controlled greenhouse environment for scoring of disease symptoms. They mapped a major QTL for resistance to pathotype I (QTL ar1, indicative marker GA16; Figure 2) to LG 2. Two QTLs against pathotype II, QTL ar2a and QTL ar2b, were identified as independent recessive major resistance loci with complementary gene action and were mapped to LGs 2 and 4, respectively (indicative markers TA130, TA72, TS72 on linkage group 4). QTL ar2a resided in close vicinity of the pathotype I specific resistance locus, indicating a clustering of resistance genes (Figure 2).

Also, Cho et al. (2004) employed both, controlled greenhouse and field conditions, to screen their intraspecific RIL mapping population with two defined isolates of pathotype I and one isolate of pathotype II. As already shown by Udupa and Baum (2003) the pattern of blight resistance in the RILs varied depending on the pathotype. The greenhouse screening with the pathotype I isolates (Ar19 and Ar21d) revealed two QTLs for resistance located on LG2A + 6B, with LOD scores of 3.08 and 2.66, respectively. Those two QTL were postulated to be joined in a single one (QTL ar 1a) on the basis of the expected linkage between LG $2 \mathrm{~A}$

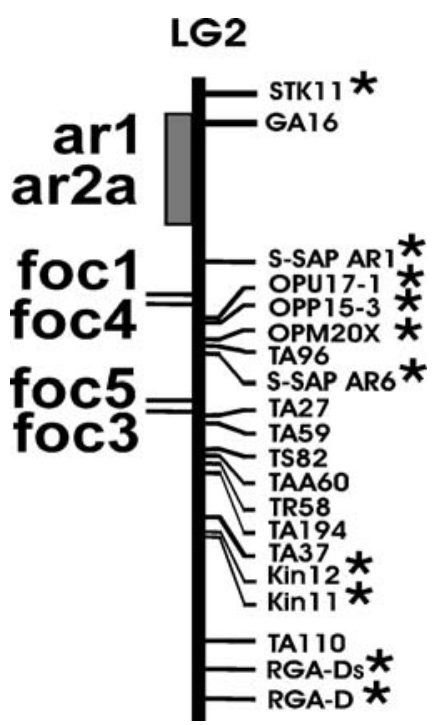

Figure 2. Detailed map of linkage group 2 in vicinity of the fusarium resistance gene clusters including fusarium resistance (foc) genes and QTL for ascochyta blight resistance (ar1, ar2a, indicated by the shaded box) on the left side of the vertical bar. Markers on the right are STMS and DAF markers from Benko-Iseppon et al. (2003) and RGA markers from Hüttel et al. (2002). Loci marked with an asterisk are potentially involved in pathogenesis, either encoding RGAs or pathogenesis-related proteins. See text for more detail.

and $\mathrm{LG} 2 \mathrm{~B}+6 \mathrm{~B}$, in accordance with the Winter et al. (2000) map (indicative markers GA20 and GA16). A second QTL (called ar1b here), located on LG 2B (indicative markers TA37 and TA200) with a LOD score of 3.69, was specific for pathotype I isolate Ar21d, suggesting that races may co-exist within the pathotypes.

Growth chamber experiments with a mixture of pathotype II isolates revealed one QTL (named QTL ar2a), which mapped to the same position on LG4A (indicative markers GA24 and GAA47, LOD score 4.17) as the QTL for blight resistance in the field (LOD score 2.83). Two QTLs for blight resistance in the field on LGIV and LGVIII of the interspecific linkage map of Tekeoglu et al. (2002) appeared to be the same as the QTL on LG4A of the map of Cho et al. (2004). Since both field experiments were conducted on the same experimental farm in Washington State, USA, ascochyta pathotype II seems to be prevalent there.

Flandez-Galvez et al. (2003a) also detected association to blight resistance in a linkage group equivalent to LG4 using a F2 population derived from an intraspecific cross. In this group, QTL 5 (indicative marker TA146) was the only one showing significant 


\begin{tabular}{|c|c|c|c|c|}
\hline Pathotype & Name of QTL & Indicative marker ${ }^{\mathrm{a}}$ & LG & Reference \\
\hline nd & 1 & GAA47 & 4 & Tekeoglu et al. (2002) \\
\hline nd & 2 & TA72, GA2 & 4 & \\
\hline \multirow[t]{3}{*}{ nd } & 1 & $\mathrm{TS} 12 \mathrm{~b}$ & & Flandez-Galvez et al. (2003b) \\
\hline & $2 / 3$ & $\mathrm{TA} 3 \mathrm{a} / \mathrm{TA} 3 \mathrm{~b}$ & & \\
\hline & $4 / 5 / 6$ & TA30/TA146/TR20 & & \\
\hline \multirow[t]{2}{*}{ nd } & AR2 & SC/OPK13 603 & 4 & Millán et al. (2003) \\
\hline & & $\begin{array}{l}\text { SC/OPM02935 } \\
\text { TA72, TA146 }\end{array}$ & & Iruela et al. (2006) \\
\hline nd & I & STMS11, GA2, GAA47, TR20 & 4 & Rakshit et al. (2003) \\
\hline I & ar1 & GA16 & 2 & Udupa and Baum (2003) \\
\hline II & ar2a & GA16 & 2 & \\
\hline II & $\operatorname{ar} 2 b$ & TA130, TA72, TS72 & 4 & \\
\hline I & ar1a & GA20, GA16 & $2 \mathrm{~B}-6 \mathrm{~B}$ & Cho et al. (2004) \\
\hline I & $\operatorname{ar} 1 b$ & TA37, TA200 & $2 \mathrm{~B}$ & \\
\hline II & ar $2 \mathrm{a}$ & GA24, GAA47 & $4 \mathrm{~A}$ & \\
\hline nd & $1^{*}$ & STMS 11, GA2, TR20 & 4 & Collard et al. (2003) \\
\hline nd & $2^{*}$ & $\mathrm{XLRRb}_{280}$ & 4 & \\
\hline
\end{tabular}

nd: not determined.

${ }^{\mathrm{a}} \mathrm{XLRRb} 280$ is an RGA marker; SCAR markers are named with SC prefix; rest are STMS markers.

* Seedling resistance.

association in two different environments (controlled and field trial), five other QTLs were also detected $(1,2,3,4,6)$ but in only in a particular environment (Table 1).

In all the studies undertaken so far, cultivated chickpea was the source of resistance to ascochyta blight. To exploit resistances available in the wild Cicer species, Collard et al. (2003) employed an interspecific $F_{2}$ population derived from a cross between a susceptible chickpea cultivar and a resistant $C$. echinospermum accession to generate a preliminary linkage map of low density. Six out of the eight detected LGs could be correlated to LGs from the integrated map (Winter et al., 2000) by STMS markers that generally function also in C. echinospermum (Choumane et al., 2000). The two remaining linkage groups contained no STMS and thus could not be related to known LGs. The $\mathrm{F}_{2}$ population was evaluated for seedling and stem resistance in glasshouse trials. Interval mapping and single-point analysis identified at least two QTLs for seedling resistance, and both were located on LG 4 (QTL 1, interval STMS 11, GA2, TR20; QTL2, no significantly linked STMS, indicative marker RGA XLLRb 280 ). Out of five markers associated with stem resistance, four were also linked to seedling resistance. No significant association of stem resistance with STMS markers was detected. A summary of the QTLs for ascochyta blight resistance detected is provided in Table 1 together with markers indicating the respective linkage groups.

The application of STMS markers in all these studies now allows us to conclude that $A$. rabiei pathotype I resistance is governed by a major QTL on LG 2 close to marker GA16 (Figure 2). This, or an adjacent locus is also partly responsible for resistance to pathotype II. Another, (eventually race-specific) QTL for resistance to pathotype I may be located on the same LG in the vicinity of marker TA37. A QTL flanked by STMS 11 and TR2 20 on LG-4 confirmed by all workers is responsible for resistance to pathotype II and eventually also for resistance during the seedling stage (see summary map in Figures 1 and 2). Since apparently all major blight resistance QTLs are tagged with STMS markers, pyramiding of resistance genes via MAS should now be feasible and awaits its proof-of-principle. The genetic control of this disease bred into cold tolerant germplasm would be a major breakthrough for yield increases in Mediterranean-type environments in many parts of the world. 
Infection of chickpea by Ascochyta rabiei: The transcriptome

Functional genomics of chickpea is still very much in its infancy, yet there is great scope for its application in the development of gene-based markers for molecular breeding of complex traits. Moreover, better knowledge of the activity of genes involved in pest and disease resistance, and tolerance to environmental stresses promises increases in productivity and yield stability. Until recently, only some 500 chickpea expressed sequence tags (ESTs) were deposited in public databases. However, more recently several groups initiated systematic gene expression analyses associated with specific stresses.

The group of Prof. W. Barz (Muenster, Germany) was the first to focus on transcriptomics of chickpea cell cultures upon infection with A. rabiei (Mackenbrock et al., 1993). On the physiological level, elicitation of cultured cells stimulated a signal transduction pathway leading to several rapid responses including an oxidative burst, extracellular alkalinisation followed by extracellular acidification, transient $\mathrm{K}+$ efflux, and activation of defence-related genes, all within $2 \mathrm{~h}$. Rapidly and transiently expressed genes encoded the first soluble enzyme in the pterocarpan biosynthesis part of the medicarpin and maackiain malonylglucoside phytoalexin pathway (Mackenbrock et al., 1993), a NADPH: isoflavone oxidoreductase (IFR; Tiemann et al., 1991), and at least eight members of the cytochrome $\mathrm{P} 450$ protein family also involved in isoflavone synthesis. Thus, it seems that isoflavone metabolism is of considerable importance for resistance to A. rabiei (Barz \& Mackenbrock, 1994; Overkamp et al., 2000). Increased expression was also found for mRNAs of rab and rac type small GTPbinding proteins (Ichinose et al., 1999), and for genes encoding two glycine-rich proteins (GRPs), which displayed maximum expression 5 days post infection and are probably involved in fortification of cell walls by oxidative cross-linking of cell wall components (Cornels et al., 2000). In planta, a pathogenesis-related thaumatin-like protein (TLP) gene, PR-5a, and a second cDNA coding for a slightly larger TLP (PR-5b), presumably located in the vacuole, were elicited much faster in an A. rabiei-resistant cultivar than in a susceptible cultivar. However, PR-5a was not effective as an antifungal agent against $A$. rabiei (Hanselle et al., 2001). Generally, genes elicited by A. rabiei could be assigned to five groups according to their function in plant metabolism including primary metabolism, regulation of gene expression, defence-related, signal transduction and catabolic pathways (Ichinose et al., 2000). Full-length sequences for chalcone synthase and phenylalanine ammonia-lyase (PAL) cDNA, both important enzymes in defence response, were provided by the same group (Hanselle et al., 1999; Hein et al., 2000). At least a part of these elicitor-induced responses are inhibited by the serine/threonin protein kinase inhibitor staurosporine and the anion channel blocker anthracene-9-carboxylic acid, and stimulated by the ser/thr protein phosphatase $2 \mathrm{~A}$ inhibitor cantharidin (Otte et al., 2001), indicating that the signal cascade leading to activation of pathogenesis-related genes requires the action of serine/threonin kinases. Interestingly, a major QTL for ascochyta resistance on LG 2 (indicative marker GA16; Figure 2) is closely linked to a serine/threonin kinase gene (STK11; Hüttel et al., 2002). To determine if this gene is the resistance gene requires more research.

However, the belief that ascochyta blight or fusarium wilt resistance in chickpea is initiated by, or correlated to, differential expression of conventional, defence-related genes may be misleading. This cautionary note refers to recent results of Cho and Muehlbauer (2004), who investigated expression patterns of genes related to defence in chickpea after pathogen inoculation and exogenous treatments with systemic signals such as salicylic acid (SA) and methyljasmonate (Me-JA). The authors demonstrated significant differential expression of the defence-related genes in two blight and SA- and Me-JA differential germplasm lines (one resistant and SA and Me-JA responsive, the other susceptible and SA and Me-JA non-responsive) after inoculation with A. rabiei and exogenous treatment with SA and Me-JA. However, resistance in the RILs from a cross of these varieties did not co-segregate with the expression of the genes induced either by the pathogen or by the signal chemicals. Also, resistance to fusarium wilt did not require induction of these genes. Moreover, these authors also did not observe a hypersensitive response (HR) in their resistant varieties, previously claimed to be part of chickpea's defence against A. rabiei (Hoehl et al., 1990). Thus, systemic regulation of defence-related transcripts associated with disease resistance in several pathosystems in e.g. Arabidopsis or other host species does not necessarily confer resistance against the two necrotrophic fungi in chickpea. Instead, either constitutively expressed or unknown defence systems independent of SA- and JA may be necessary for resistance against these pathogens (Cho \& Muehlbauer, 2004). 
New mechanisms of defence have to be searched for depending on the pathosystem, since SA- and Me-JAindependent mechanisms of resistance are also found in other species (Branding et al., 2000; Roetschi et al., 2001). These are eventually only detectable by "opensource" transcription profiling systems such as SuperSAGE (Matsumura et al., 2003) that are not based on "prejudices".

\section{Targeting of Fusarium oxysporum resistance genes}

To date, eight races of Fusarium oxysporum f. sp. ciceris have been reported from India, Spain and the United States $(0,1 \mathrm{~A}, 1 \mathrm{~B} / \mathrm{C}, 2,3,4,5$ and 6; Haware \& Nene, 1982; Jiménez-Díaz et al., 1993; Jiménez-Gasco et al., 2004). Each of these races forms a monophyletic lineage, which acquired its virulence on different chickpea lines in simple, stepwise patterns (Jimenez-Gasco et al., 2004). Over 150 sources for resistance have been identified, and some are resistant to more than one race. The genetics of resistance is, however, complex, since at least for resistance to race 1 a minimum of two out of three detected resistance genes are required (van Rheenen, 1992).

Several studies in inter- and intraspecific RIL populations demonstrated the organisation of resistance genes for fusarium wilt races 1, 3, 4 and 5 (foc 1 and foc3, foc4 and foc5; Mayer et al., 1997; Ratnaparkhe et al., 1998; Tullu et al., 1998; Winter et al., 2000; Sharma et al., 2004) in two adjacent resistance gene clusters on LG 2 flanked by STMS markers GA16 and TA96 (focl-foc4 cluster) and TA96 and TA27 (foc3foc 5 cluster) respectively (Figure 2). However, not only resistance genes per se, but also other sequences coding for proteins putatively involved in the reaction of chickpea to pathogen attack were localised between, or in close vicinity, to the fusarium resistance gene clusters. For example, the sequence of one of the markers most tightly linked to the foc 4 and foc 5 loci is highly similar to a PR-5 thaumatin-like protein gene and another one is homologous to the gene for anthranilate $N$-hydroxycinnamoyl-benzoyltransferase, a regulator of the phytoalexin pathway, both important components of the plant's defence against pathogens (Figure 2). In the Arabidopsis genome, homologues of these genes are located in close vicinity on short segments of chromosome 1 and 5, respectively, suggesting synteny to the fusarium resistance gene cluster(s) of chickpea (Benko-Iseppon et al., 2003). Besides the fusarium resistance genes, the resistance loci arl and ar2 $a$ against two different pathotypes of $A$. rabiei were also localised on LG 2 close to each other and to the foc gene clusters (Udupa \& Baum, 2003; Figure 2). Moreover, several potential resistance and pathogenesisrelated genes were localised on this LG (Hüttel et al., 2002; Pfaff \& Kahl, 2003). It may therefore well be justified to call LG 2 a hot spot for pathogen defence.

However, not all fusarium wilt resistance genes are located on LG 2 of the genetic map of Winter et al. (2000). For example, Rubio et al. (2003) not only showed that two different genes can confer resistance to race $0\left(f o c O_{1}\right.$ and $\left.f_{o c} O_{2}\right)$ but also demonstrated linkage of the $f o c O_{1}$ to RAPD marker $O P J 2 O_{600}$ (resistance derived from line JG62). More recently, this locus has been mapped on LG5 tightly flanked by a RAPD ( $3 \mathrm{cM}$ apart) and an STMS (2 cM apart) marker (Cobos et al., 2005).

\section{Cloning resistance genes via the candidate gene approach}

Most resistance proteins are receptor-like protein kinases of the nucleotide-binding site-leucin-rich-repeat (NBS-LRR) class and composed of different combinations of conserved elements. Therefore, resistance gene analogues (RGAs) or candidate resistance genes can be isolated by PCR amplification with degenerate oligonucleotide primers derived from conserved amino acid motifs in the NBS (Kanazin et al., 1996; Shen et al., 1998). This approach was used by Hüttel et al. (2002) in an effort to directly clone $R$-genes against $F$. oxysporum and A. rabiei. These authors isolated a series of RGAs from both $C$. arietinum and $C$. reticulatum using two degenerate primer pairs targeting sequences in the NBS domain. A total of 48 different RGAs fell into 9 different sequence classes, and were members of the Toll-interleukin receptor (TIR)-NBS-LRR and coiledcoil (CC)-NBS-LRR groups. Thirty of these RGAs were mapped on the reference genetic map of chickpea (Winter et al., 2000), where they could be located on principally five linkage groups, some of them as clusters on LGs 2 and 5, respectively (Figure 1). One such cluster with the prominent RGA CaRGA-D mapped in the region harbouring the fusarium resistance gene cluster, but not close enough to the resistance to be a real fusarium resistance gene (Figures 1 and 2). Besides this most comprehensive direct approach towards the isolation of resistance genes from chickpea, FlandezGalvez et al. (2003b) mapped 12 RGA markers that clustered on three LGs, and Collard et al. (2003), in a preliminary investigation of QTLs from C. echinospermum associated with seedling resistance to ascochyta 
blight, mapped another two. One of them, XLRRb, could be located within a QTL for seedling resistance. However, the low LOD score of 2.6 suggests that it is probably not the resistance gene itself, but may be part of a resistance gene cluster containing this gene. Also, Tekeoglu et al. (2002) mapped an anonymous RGA marker to LG 3. In summary, efforts to directly clone a fusarium or ascochyta resistance gene via the candidate gene approach are not yet successful. A possible reason for the failure of this approach may be the low level of polymorphism in the chickpea genome combined with the high conservation of the NBS-coding region used for designing the primers that prevented the mapping of many RGAs. Targeting at the more variable LRRcoding region of the genes in accord with new methods to detect polymorphisms such as EcoTILLING (Comai et al., 2004) may be more successful.

\section{Breeding for tolerance to abiotic stresses}

\section{Chilling tolerance at flowering}

The change from spring to winter sowing in chickpea, resulting in efficient use of rain water and increased yield in Mediterranean type environments, implies that tolerance to low temperature becomes important for further crop improvement. Both freezing (below $\left.-1.5^{\circ} \mathrm{C}\right)$ and chilling $\left(-1.5-15^{\circ} \mathrm{C}\right)$ are known to affect chickpea at various stages of development from germination to maturation (Croser et al., 2003b). Abortion of flowers at temperatures of $15^{\circ} \mathrm{C}$ and below are documented from field in Australia (Siddique \& Sedgley, 1986), the Mediterranean (Singh, 1993) and India (Savithri et al., 1980; Srinivasan et al., 1998), and in growth room studies (Srinivasan et al., 1999; Clarke \& Siddique, 2004; Nayyar et al., 2005). Studies at low temperatures in controlled environments demonstrated that pollen tubes derived from chilling-tolerant phenotypes grew faster down the style to the ovary for fertilization than pollen derived from chilling-sensitive plants (Clarke \& Siddique, 2004). Such knowledge of location and timing of chilling sensitive stages during reproduction in chickpea enables precise screening of germplasm for this trait. The variation in pollen derived from different genotypes and the co-expression of the trait in the pollen and its mother plant (haplo-diplo expression) opens up the possibility of using pollen selection to improve chilling tolerance.

The potential of pollen selection as a breeding tool, whereby selection pressure is applied at the gameto- phytic stage in the life cycle, has been demonstrated in a wide range of species (review by Hormaza \& Herrero, 1996). Recently, this novel approach has been applied to chickpea improvement for winter sowing in the cool dry-land environment of southern Australia, contributing to the release of the two chilling tolerant desi chickpea cultivars Sonali and Rupali (Clarke et al., 2004). During the early generations of breeding, selection pressure was applied to the pollen tubes, as they grew down the style to fertilise the ovary, by chilling the mother plants for 3 days immediately after hand pollination. The pollen selection cycle can be repeated by cross pollination and backcrossing of sensitive cultivars with heterozygous pollen from $\mathrm{F}_{2}$ donor plants segregating for chilling tolerance (Figure 3 ). The new cultivars set pods when the average maximum temperature over a 24 -h period is $12^{\circ} \mathrm{C}$, compared to the check cultivars, which abort flowers at $15^{\circ} \mathrm{C}$. In the field, this translates to successful pod set about 2 weeks earlier, resulting in significantly higher yields in low-rainfall environments. Previous success in breeding chillingor freezing-tolerant chickpea lines has been reported at ICRISAT (Khanna-Chopra \& Sinha, 1987; ICRISAT, 1994) and at ICARDA (Singh, 1987).

Early identification of chilling-tolerant types combined with pollen selection has great potential to accelerate breeding for cold tolerance. Molecular markers based on amplified fragment length polymorphisms (AFLPs) have been linked to the trait using bulked segregant analysis for $F_{2}$ progeny of a cross between the chilling-sensitive cultivar Amethyst and the chillingtolerant ICCV 88516 (Clarke \& Siddique, 2003). Putative markers linked to traits for both chilling tolerance and chilling sensitivity overcome the limitations of the dominant AFLP marker system. Six pairs of specific 18-24-mer primers were designed directly from the sequence of the AFLP-based markers. The primers were then used to amplify the defined DNA fragment from genomic DNA of individual $\mathrm{F}_{4}$ progeny with known phenotypes in an attempt to develop SCAR markers (Paran \& Michelmore, 1993). The most promising primers were based on a 560 bp fragment containing a simple sequence repeat ( $3 \mathrm{bp}$ repeat microsatellite), with 9 repeats in the susceptible parent and 10 in the tolerant parent (Clarke, unpublished). The three-base difference was visualised on a vertical acrylamide gel and was very useful in the selection of chilling-tolerant progeny derived from crosses between ICCV 88516 and Amethyst. Unfortunately, there has been no success in applying these SCAR markers to other breeding materials. 


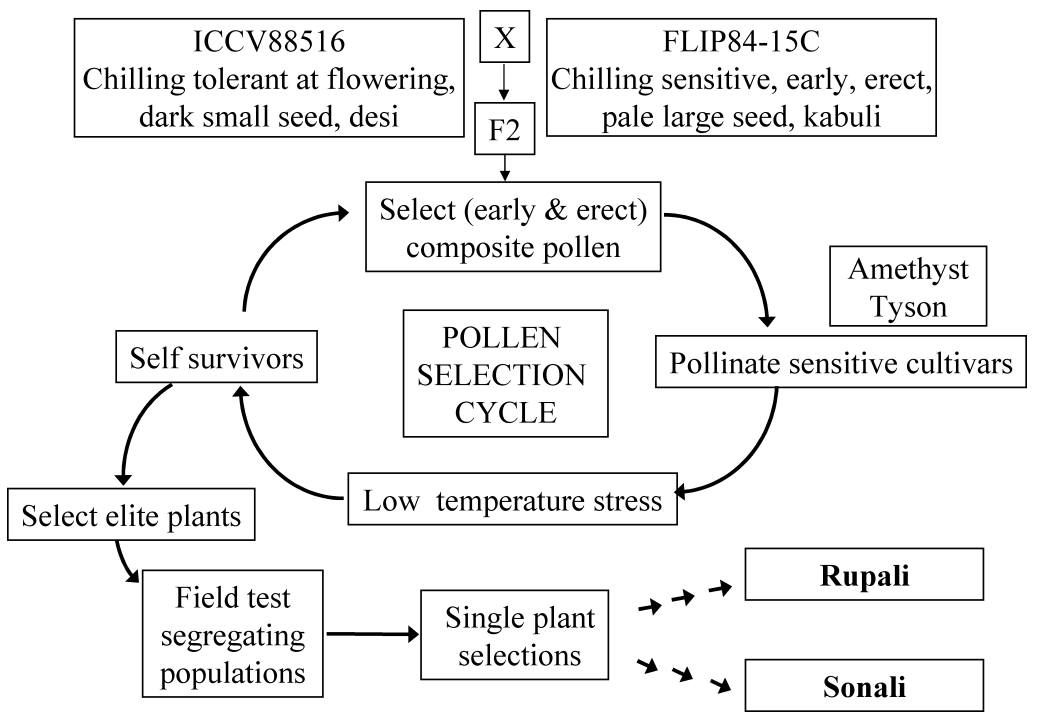

Figure 3. Schedule for chickpea improvement, including repeated cycles of pollen selection at low temperature stress, which was successfully used to develop new cultivars for Australia (source: Clarke et al., 2004).

A new method developed for marker-assisted breeding in lupins (Yang et al., 2001) could also be considered for chickpea in the future. Microsatelliteanchored fragment length polymorphism (MFLP) is highly efficient in producing DNA polymorphisms, and many MFLP markers can easily be converted into sequence-specific, simple PCR-based co-dominant markers. Several such markers are now being fully implemented in the Australian national lupin breeding program to select for resistance to fungal diseases (Yang et al., 2004).

Difficulties in screening and breeding for tolerance to low temperatures are further confounded by low genetic variability within cultivated chickpea (Abbo et al., 2003). Relatives of chickpea among the wild Cicer species offer a valuable genetic resource to overcome these limitations (Berger et al., 2003; Shan et al., 2005). Tolerance to cold has been reported in five annual and one perennial species (van der Maesen \& Pundir, 1984; Singh et al., 1991, 1995, 1998; review by Croser et al., 2003a). The original collection and many selections of annual Cicer species held in world gene banks were analysed using DNA molecular markers, which are not affected by environmental influences, providing useful data for the selection of suitable parents for crosses (Iruela et al., 2002; Nguyen et al., 2004; Shan et al., 2005). To a certain extent, it will also be possible to use chickpea-derived STMS markers for the marker-based analysis of wide crosses because many STMS can be transferred between Cicer species (Choumane et al., 2000). Barriers in wide crosses are also being addressed through international collaboration with the aim to use embryo rescue to overcome incompatibility (Mallikarjuna, 1999; Clarke et al., 2004b).

Yield improvement in drought-prone environments: Altering phenology and root traits

\section{Flowering time}

Since about $90 \%$ of the chickpea crop is grown under rain-fed conditions, drought is the most important stress that limits chickpea production and yield stability. Therefore, matching growth duration of crop varieties to soil-moisture-availability is critical to realise high seed yield (Siddique et al., 2003). Time of flowering is a major trait of a crop's environmental adaptation, particularly when the growing season is restricted by terminal drought and high temperatures. Developing short-duration varieties has to date been the most effective strategy for minimizing losses from terminal drought, as early maturity helps the crop to avoid the period of greatest stress (Kumar et al., 1996; Kumar \& Abbo, 2001). However, since yield is generally correlated with the length of crop duration under favourable 
growing conditions, any reduction of crop duration below the optimum would have a penalty in yield (Saxena, 1987; Turner et al., 2001). Kumar and Rao (2001) developed the world's shortest-duration chickpea variety that was recently released as a catch cultivar for cultivation between rice and wheat in the Punjab province of India (Sandhu \& ArasaKesary, 2003). The new variety led to substantial increases in chickpea area and productivity in short growing-season environments and expanded options to include chickpea in many prevailing and evolving new-production systems, such as rice fallows (Kumar \& Abbo, 2001).

In Mediterranean environments, early flowering has a positive effect on seed yield (Siddique et al., 2003; Rubio et al., 2004). In a 4-year, multi-location trial in Southern Spain, early flowering was generally beneficial for productivity explaining $26 \%$ of the variation in yield in winter and $77 \%$ in spring-sown crops (Rubio et al., 2004). Chickpea generally is a long day plant (van der Maesen, 1972; Summerfield et al., 1981; Sethi et al., 1981). Day-length-insensitive lines have been obtained from crosses involving germplasm from low latitudes such as East Africa, the Indian Plateau and Mexico. Also, a day-length-insensitive line of chickpea from Iran has been reported (ICC 5810; Roberts et al., 1985). Early flowering lines derived from ICCV 96029 are also exploited in short-duration environments defined by low temperatures such as in Canada (Kumar \& Abbo, 2000).

Limited information is available on the genetics of flowering in chickpea. A major gene $(e f l-1)$ for time of flowering was reported by Kumar and van Rheenen (2000), and another one ( $p p d$ ) by Or et al. (1999). The latter gene controls time to flowering through photoperiod response (Hovav et al., 2003). It is unclear whether the $e f l-1$ and $p p d$ genes differ from each other, as allelic tests have not been performed. The efl- 1 gene is extensively used to develop early maturing varieties (Kumar \& Abbo, 2001; Musa et al., 2001). Anupama (personal communication) named two genes, $n f f-1$ and $n f f-2$, that govern node number to first flowering, an indication of time of flowering. Significant correlation between time of flowering and number of nodes up to first flower was observed. Cho et al. (2002) mapped a QTL for days to $50 \%$ flowering to LG 3. Another QTL was also located on this linkage group in an interspecific RIL population and explained $28 \%$ of the total phenotypic variation (Cobos et al., 2004). Clearly, more research is required to understand this important phenological trait that can lead to major breakthroughs in increasing chickpea's productivity.

\section{Drought tolerancelavoidance}

Conventional breeding for drought tolerance is based on selection for yield and its components under a given water-limited environment. Because the large environmental variation necessitates evaluation of material at several locations and/or over years, trait-based selection could have an advantage. Efforts have been made to identify morphological traits that could contribute to drought tolerance/avoidance in chickpea (Turner et al., 2001). Two important drought avoidance traits have been suggested: a large root system is apparently more efficient for extraction of available soil moisture, and a smaller leaf area helps to reduce transpirational water losses (Saxena, 2003). More than 1500 chickpea germplasm and released varieties were screened for drought tolerance at ICRISAT. The most promising drought tolerant variety was ICC 4958 that had $30 \%$ more root volume than the popular variety Annigeri (Saxena et al., 1993). Promising drought-tolerant lines have been developed using ICC 4958 as one of the parents. Yield-based selections were effective in producing varieties with high yield, and trait-based selections resulted in lines with better drought tolerance obtained from a three-way cross involving ICC 4958, Annigeri and ICC 12237, a fusarium wilt resistant accession (Saxena, 2003). Efforts were also made to combine large roots trait of ICC 4958 and the few pinnules (smaller leaf area) trait of ICC 5680. Several lines combining these traits were more drought tolerant and yielded similar to the high yielding parent (Saxena, 2003).

Selection for root traits is very difficult, since it involves laborious methods such as digging and measuring roots. Molecular tagging of major genes for root traits may enable MAS for these traits and could greatly improve the precision and efficiency of breeding. A set of 257 recombinant inbred lines (RILs) was developed from the cross Annigeri $\times$ ICC 4958 at ICRISAT and glasshouse-evaluated to identify molecular markers for root traits. Over 250 STMS and 100 EST markers were initially screened on parents of the RILs. Fifty-seven STMS markers detected polymorphisms and were mapped on the RIL population. A QTL flanked by STMS marker TAA 170 and TR 55 on LG 4A was identified that accounted for maximal phenotypic variation in root length $\left(\mathrm{Ra}^{2}=\right.$ $33.1 \%)$, root weight $\left(\mathrm{Ra}^{2}=33.1 \%\right)$ and shoot weight $\left(\mathrm{Ra}^{2}=54.2 \%\right)$ (Chandra et al., 2004; Buhariwalla et al., personal communication). The locus also accounted for substantial variation $\left(\mathrm{Ra}^{2}\right.$ of $\left.6.7-33.7 \%\right)$ 
observed in these traits under simulated and actual field conditions.

Recently, the chickpea minicore collection of 211 accessions was evaluated for root traits along with 12 popular cultivars and 10 accessions of wild annual species (Krishnamurthy et al., 2003). The statistical differences of entries for both, root and shoot traits, were significant $(p<0.001)$. The root and shoot growth of the wild species was relatively poor compared to $C$. arietinum lines. However, several $C$. arietinum genotypes with higher maximum root depth and similar root mass than ICC 4958 were identified. Now, these newly identified genotypes serve as valuable alternative source for large root traits. Four accessions that contrasted extremely in rooting depth and total root biomass (ICC 8261, and ICC 4958 with large and ICC 283 and ICC 1882 with small roots) were selected for development of new mapping populations which will be useful in identification of additional markers for QTLs of root traits useful for drought avoidance.

Osmotic adjustment, the active accumulation of solutes within plant tissues in response to soil water potential (Morgan, 1984), is positively correlated with yield under drought environments in several cereals (Morgan, 1984; Morgan et al., 1986; Blum, 1989). Genotypic variation for osmotic adjustment also exists in chickpea (Morgan et al., 1991; Leport et al., 1999; Turner et al., 2001; Abbo et al., 2002; Moinuddin \& Khanna-Chopra, 2004). However, the correlation of osmotic adjustment and yield under drought stress is not clear, since a positive association of osmotic adjustment with productivity (Morgan et al., 1991; Moinuddin \& Khanna-Chopra, 2004) as well as no influence has been reported (Leport et al., 1999). The heritability of osmotic adjustment is low $\left(h^{2}=0.20\right.$ 0.33 ), indicating that gains from selection for increased osmotic adjustment are likely to be small (Abbo et al., 2002).

Genetic engineering is currently explored for enhancing the levels of drought tolerance in chickpea. ICRISAT has developed an efficient transformation and regeneration system (Jayanand et al., 2003), and developed transgenic plants with a dehydration responsive element (DRE) construct, where the expression of the DREB1A cDNA is driven by a droughtresponsive rd29A promoter (ICRISAT, 2003). This construct is expected to enhance tolerance to several abiotic stresses, such as drought, chilling temperature and salinity, as it regulates a number of genes that act together in enhancing the tolerance to these stresses (Kasuga et al., 1999). The T1 generation transgenic plants are currently undergoing molecular characterisation. Plants have also been transformed with the gene P5CSF-129A that increases proline accumulation and improves tolerance to osmotic stress (Hong et al., 2000). Fifteen independently transformed lines tested positive in PCR, Southern blot hybridisation, and RT-PCR for integration and expression of the transgene. Some selected lines showed up to 15 -fold overproduction of proline and a concomitant decline in free radicals. These lines are currently advanced to T3 generation for physiological characterization (ICRISAT, 2003).

\section{Transcriptomics approaches to improve yield in drought-prone environments}

To date, little attention has been paid to defining the molecular genetic determinants associated with drought avoidance and root traits. In order to generate markers for candidate gene mapping studies, functional genomics and allele mining of germplasm collections, only recently a targeted EST approach was employed at ICRISAT to identify genetic elements with putative involvement in chickpea drought avoidance and tolerance. Subtractive suppression hybridisation ( $\mathrm{SSH}$ ) was used for the isolation and characterisation of root-specific genes differentially expressed between two closely related chickpea genotypes (ICC 4958 and Annigeri) possessing different sources of drought avoidance and tolerance (Saxena et al., 1993; Saxena, 2003; Berger et al., 2003). The SSH process resulted in approximately 4000 clones including genes associated with root system development from the genotype ICC 4958 (tester), and possibly also some highly constitutively expressed genes from Annigeri. A total of 2858 EST sequences were analysed, of which 507 unique ESTs are available at GeneBank (CK148643-CK149150). All ESTs can also be accessed via a relational database at http://www.icrisat.org/gt1/Cpest/Home.asp (Jayashree et al., 2005). Tentative functional annotations with tBLASTx allowed the grouping of EST sequences into 12 general categories based on the biochemical functions of the predicted proteins as shown in Figure 4 (Buhariwalla et al., 2005). More than three-quarters of the 210 consensus sequences $(77 \%$ equivalent to 164 contigs) were significantly similar (tBLASTx >100) to sequences in public databases. Over 379 sequences were similar at the nucleotide level to entries in the Medicago Gene Indices and 323 to the Soybean Gene Index (based on a cut-off 


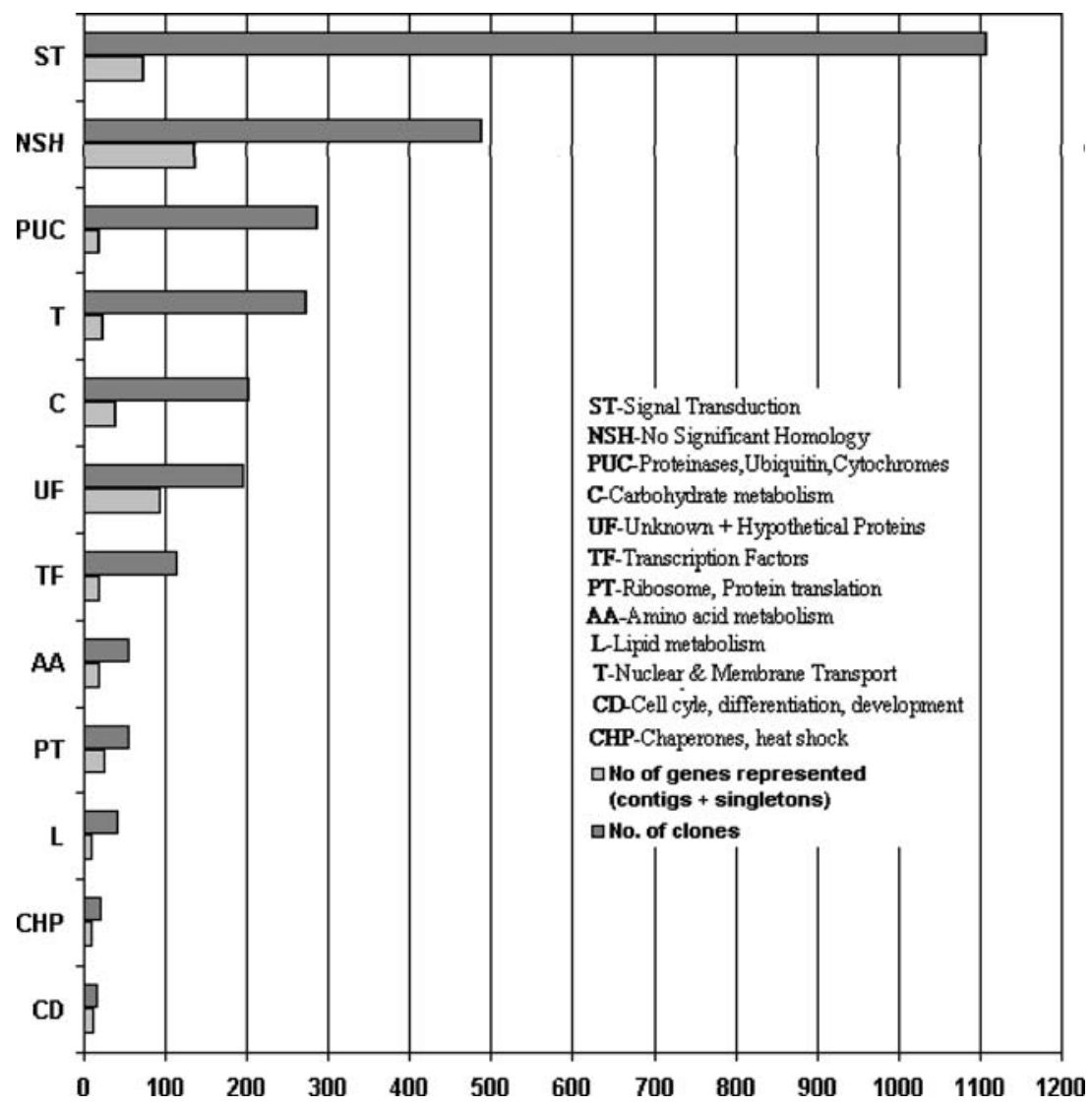

Figure 4. A summary of the number of clones and genes from chickpea roots in functional categories based on alignments with public databases in November 2004. Percentages indicate proportion of unigenes from the total number of unigenes identified in the whole dataset (source: Buhariwalla et al., 2005).

score of 200; $e<10-5$ ). ESTs involved in signal transduction constituted the most abundant class of root ESTs (Figure 4), consisting largely of WD-repeat proteins $(40 \%)$, protein kinases $(25 \%)$ and arm-repeat containing proteins $(13 \%)$. These sequences play a role in stress-response pathways in several organisms and thus provide an ideal resource for the development of candidate gene markers for studying root trait components and stress signalling response to drought. Other ESTs in chickpea root tissue that may be important for constitutive stress response and development include transcripts for proteases, T6P synthase, non-specific lipid transfer proteins, MRP-like $\mathrm{ABC}$ transporters, chaperones, HSP70, TCP-1-alpha, bZIP transcription factor, calcium ATPases, protein kinases, MRP4 glutathione-conjugate transporter, glutathione $S$-transferase, phosphoenol pyruvate carboxylase and $S$-adenosyl methionine synthetase. Primers designed from a selection of these EST are currently screened if they amplify polymorphic amplicons from parental genotypes of several recombinant inbred line populations designed specifically for mapping the root trait components of drought tolerance. Initial results suggest that around $20 \%$ of EST markers generated from this SSH library are polymorphic in these mapping populations, either directly or as cleaved amplified polymorphic sequence (CAPS) markers (Buhariwalla et al., 2005). Future developments will include the use of these EST markers for candidate gene mapping, allele mining of chickpea germplasm collections and the development of single nucleotide polymorphism (SNP) markers from the most promising EST markers.

Another study investigated changes in gene expression accompanying the adaptation to drought. Employing repetitive rounds of cDNA subtraction and differential DNA-array hybridisation followed by Northern blot analysis, Boominathan et al. (2004) 
identified 101 dehydration-inducible transcripts in seedlings all of which were also induced by absisic acid (ABA). Steady-state expression levels of the dehydration-induced transcripts were monitored during the recovery period between two consecutive dehydration stresses. Seven of them maintained more than threefold expression after $24 \mathrm{~h}$ and more than twofold expression over the basic level even at $72 \mathrm{~h}$ after the end of stress. Noticeably, all of them were inducible by exogenous ABA treatment. When the seedlings were allowed to recover to a similar level after exposure to exogenous ABA, the steady-state abundance of six of them followed totally different kinetics returning to the basal expression level within $24 \mathrm{~h}$. This observation suggests a correlation between the longer period of abundance of those transcripts in the recovery period and improved adaptation of the plants to subsequent dehydration stress and indicate that both ABAdependent and -independent mechanisms are involved in the maintenance of the messages from the previous stress experience. Thus, the storage of stress-related messages could be one of the components necessary for increased tolerance of pre-exposed plants against subsequent exposures to stresses such as dehydration shocks.

The results presented by Boominathan et al. (2004) suggest that dehydration-stress-related gene expression is generally also regulated by ABA. However, Romo et al. (2001) demonstrated that at least the expression of two late embryo abundant (LEA) genes (CapLEA-1 and -2) in seedlings was not affected by ABA, but was up-regulated by dehydration stress imposed by $\mathrm{NaCl}$ and polyethylene glycol (PEG) treatment. PEG and, to an lesser extent, NaCL, but not ABA, also elicited the expression of a lipid transfer protein (LTP) gene (CapLTP) in almost all seedling tissues and especially in cotyledons to high levels. In this study, differential screening of a cDNA library from PEG-treated seedlings identified a total of seven up-regulated and six down-regulated cDNAs. In addition to those studied in more detail and mentioned earlier, up-regulated cDNAs coded for a proline-rich protein (PRP), a putative imbibition protein, a Glyoxylase I (GLX-I) gene and a protein of unknown function.

\section{Salinity tolerance}

Grain legumes, in general, are sensitive to salinity, and within legumes, chickpea, faba bean and field pea are more sensitive than other food legumes (Maas \&
Hoffman, 1977). The soil salinity affects germination resulting in poor plant stand. Chickpea plants show reduction in growth, high anthocynin pigmentation of foliage in desi type and yellowing of foliage in kabuli type, reduction in biomass, seed size and grain yield. Only salt-tolerant cultivars can be grown successfully in soils having electrical conductivity (ECe) higher than $4.0 \mathrm{dS} / \mathrm{m}^{-1}$.

The levels of salinity tolerance identified in chickpea are low to moderate. Several tolerant sources have been identified in India (Dua \& Sharma, 1995; Kathiria et al., 1997), Pakistan (Asharf \& Waheed, 1992) and Australia (Maliro et al., 2004). The salt-tolerant lines CSG 88101 and CSG 8927 identified by Dua and Sharma (1995) had lower $\mathrm{Na}^{+}$in roots than the sensitive genotypes. A salinity-tolerant desi variety, Karnal Chana 1 (CSG 8963), which can be grown in saline soils with ECe between 4 and $6 \mathrm{dS} / \mathrm{m}$, has been released in India. Recently, 252 germplasm accessions (including 211 accessions of mini-core collection) and breeding lines were screened for salinity tolerance at ICRISAT. The majority of the highly tolerant genotypes were of kabuli type, whereas the majority of the highly sensitive accessions were of desi type (Serraj et al., 2004). None of the 19 accessions of five annual wild species (C. reticulatum, C. echinospermum, C. bijugum, C. judaicum, C. pinnatifidum) studied by Maliro et al. (2004) in Australia were found tolerant to salinity.

\section{Conclusions}

Increasing and stabilising seed yield while minimising inputs is the major aim of chickpea breeding. This goal can be achieved by cultivars better adapted to the various stresses in local environments. Besides this major challenge, preferences of consumers and industry as well as health aspects need to be considered.

Drought and cold are currently the main abiotic constraints to improve chickpea productivity. There is no simple way to breed for drought or cold resistance. However, in particular environments some metabolic processes can be modified through breeding, either as single traits (e.g. pollen fertility under cold stress) or as a combination of traits (e.g. large root trait in combination with small leaf area for drought). Matching plant phenology to the environment also contributes to breeding successes. Whether trait-based breeding is successful also for tackling biotic stresses, the second most important cause for unstable and low seed yields, needs to be determined for each pathogen and 
insect pest. For example, resistance to fusarium wilt seems to be caused by clearly defined and tractable race-specific genes that may be combined with other desired traits with relative ease. Ascochyta resistance, however, becomes more and more obscure despite the fact that QTLs for resistance have been localised at a few loci in the chickpea genome. The possible existence of races within the pathotype classes, the possible association of resistance with unknown defence pathways, and most importantly, the failure of conventional breeding to efficiently control the pathogen despite all efforts, call for a thorough, in-depth investigation of the interaction of host and pathogen. It is likely that here gene-based breeding strategies need to be complemented by trait-based approaches. A much better understanding of the genetic basis of virulence and its expression as well as the population structure of the pathogen is required.

Trait-based breeding, however, requires trait dissection into components, defined genetic sources for these components and conditions to test for them. Moreover, well-tailored segregating populations are needed for pyramiding of resistance genes or QTLs controlling diseases. This is where molecular breeding enters the stage. STMS markers remain the marker of choice for many breeding programs and have been particularly useful for the comparison of chickpea maps among laboratories. Clearly, more markers are needed to cover the whole genome with a dense network to dissect adjacent QTLs into single factors, a prerequisite for pyramiding of genes positively influencing one or more characters. However, this network of markers should not be based solely on anonymous dominant or even STMS markers, but on gene-based markers, wich could allow us to compare maps from chickpea and related legumes. Thus, chickpea scientists will certainly benefit from the progress achieved in the model legumes Medicago truncatula and Lotus japonicus, or better investigated crops like soybean or pea.

Transcriptomics applied to chickpea has revealed an insight into mechanisms of drought tolerance/avoidance and pathogenesis-related and developmental processes. The future will certainly see much more impact of transcriptomics in chickpea breeding including application of microarrays. Thus, it will soon be possible to identify genes controlling complex traits by simply hybridising cDNAs to specialised chips. If combined with maps generated from markers detecting SNPs in differentially expressed genes such as single nucleotide amplification polymorphism markers (SNAP; Drenkard et al., 2000; Hayashi et al., 2004), it may be possible to land directly in the gene of interest as demonstrated for mouse (Schadt et al., 2003). The determination of genetic variability in these genes in the chickpea germplasm will then be the next step towards targeted molecular breeding and more efficient germplasm management.

Efforts to employ MAS have been initiated. However, the following aspects require more research: (i) the saturation of genomic areas of interest with markers, and their polymorphism in different genetic backgrounds (especially within $C$. arietinum); (ii) the mapping of resistance genes for fusarium wilt still not sited in current genomic maps which require the development of new RIL populations; (iii) the integration of genes or QTL controlling ascochyta blight resistance already located in different populations while simultaneously considering the importance of pathotype differentiation for this pathogen; and (iv) mapping and integration into the current genomic map of genes or QTL controlling tolerance to abiotic stresses such as chilling and freezing, drought, earliness and salinity, in addition to molecular markers tagging these traits. Insufficient efforts have been undertaken to target resistances to minor pests and diseases. Current mapping populations, available through the International Chickpea Genomics Consortium (http://www.icgc.wsu.edu/), should be evaluated for these traits in the first instance. Alternatively, new mapping populations segregating for these traits could be developed. Infestation of developing chickpea seeds by Helicoverpa larvae is a problem of pressing demand for increasing chickpea yield. However, this problem may be difficult to address by conventional breeding, since neither trypsin nor gut proteinase inhibitors that could prevent the larvae from feeding are available from chickpea or from wild Cicer species. Although there is now some evidence of antibiosis in several species of Cicer (Sharma et al., 2005), transgenic approaches may be required to develop new cultivars resistant to this ferocious pest (Patankar et al., 1999).

The development of molecular markers and of even more efficient tools in plant breeding will continue to be a very dynamic process in the coming years. Chickpea breeders look forward to a time when the presence of a gene is identified directly from a sample of a plant or its seed without resorting to the lengthy process of screening for physical and chemical characteristics. It is hoped that chickpea breeders, molecular biologists, geneticists and physiologists coordinate their effort to integrate and use molecular techniques along with classical breeding methods for chickpea improvement. 


\section{Acknowledgements}

Univ. of Córdoba research was supported by CICYT (Contract No. AGL2001-2018-C02-01) and EU (Ascorab, Contract No. ICA4-CT-2000-30003). CLIMA research on chickpea is supported by GRDC, ACIAR and COGGO. Research of PW and GK was supported by the Bundesminister für wirtschaftliche Zusammenarbeit (BMZ, Project No. 2001.7860.8001.00), EU (IP Grainlegumes, Contract No. FoodCT-2004-506223) and IAEA (Research Contract 10974/R2).

\section{References}

Abbo, S., J. Berger \& N.C. Turner, 2003. Evolution of cultivated chickpea: Four bottlenecks limit diversity and constrain adaptation. Funct Plant Biol 30: 1081-1087.

Abbo, S., N.C. Turner, R.J. French \& J. Berger, 2002. Breeding for osmotic adjustment in chickpea (Cicer arietinum L.). In: J.A. McComb (Ed.), Plant Breeding for the 11th Millenium: Proceedings of the 12th Australian Plant Breed Conference, 1520 September 2002, Australian Plant Breeding Association Inc., Perth, Western Australia, Australia, pp. 463-467.

Abbo, S., C. Molina, R. Jungmann, M.A. Grusak, Z. Berkovitch, Ruth Reifen, G. Kahl, P. Winter \& R. Reifen, 2005. Quantitative trait loci governing carotenoid concentration and weight in seeds of chickpea (Cicer arietinum L.). Theor Appl Genet 111: 185195 .

Agharkar, S.P., 1991. Medicinal Plants of Bombay Presidency, pp 62-63. Scientific Publications, Jodhpur, India.

Ansari, M.A., B.A. Patel, N.L. Mhase, D.J. Patel, A. Douaik \& S.B. Sharma, 2004. Tolerance of chickpea (Cicer arietinum L.) lines to root-knot nematode, Meilodogyne javanica (Treub) Chitwood. Genet Resour Crop Evol 51: 449-453.

Arumuganathan, K. \& E.D. Earle, 1991. Nuclear DNA content of some important plant species. Plant Mol Biol Rep 9: 208-218.

Asharf, M. \& A. Waheed, 1992. Screening chickpea (Cicer arietinum L.) for salt tolerance. Tropenlandwirt 93: 45-55.

Barve, M.P., T. Arie, S.S. Salimath, F.J. Muehlbauer \& T.L. Peever, 2003. Cloning and characterization of the mating type (MAT) locus from Ascochyta rabiei (teleomorph: Didymella rabiei) and a MAT phylogeny of legume-associated Ascochyta spp. Fungal Genet Biol 39: 151-167.

Barz, W. \& U. Mackenbrock, 1994. Constitutive and elicitation induced metabolism of isoflavones and pterocarpans in chickpea (Cicer arietinum L.) cell-suspension cultures. Plant Cell Tissue Organ Culture 38: 199-211.

Benko-Iseppon, A.M., P. Winter, B. Huettel, C. Staginnus, F.J. Muehlbauer \& G. Kahl, 2003. Molecular markers closely linked to fusarium resistance genes in chickpea show significant alignments to pathogenesis-related genes located on Arabidopsis chromosomes 1 and 5. Theor Appl Genet 107: 379-386.

Berger, J., S. Abbo \& N.C. Turner, 2003. Ecogeography of annual wild Cicer species: The poor state of the world collection. Crop Sci 43: 1076-1090.
Blum, A., 1989. Osmotic adjustment and growth of barley genotypes under drought stress. Crop Sci 29: 230-233.

Boominathan, P., R. Shukla, A. Kumar, D. Manna, D. Negi, P.K. Verma \& D. Chattopadhyay, 2004. Long term transcript accumulation during the development of dehydration adaptation in Cicer arietinum. Plant Physiol 135: 1608-1620.

Brading, P.A., K.E. Hammond-Kosack, J.D.G. Parr \& A. Jones, 2000. Salicylic acid is not required for $C f$-2- and $C f$-9-dependent resistance of tomato to Cladosporium fulvum. Plant J 23: 305-318.

Buhariwalla, H.K., B. Jayashree \& J.H. Crouch, 2005. Development of ESTs from chickpea roots and their use in diversity analysis of the Cicer genus. BMC Plant Biol 5: 16.

Caetano-Anollés, G., B.J. Bassam \& P.M. Gresshoff, 1991. DNA amplification fingerprinting using short arbitrary oligonucleotide primers. Biotechnology 9: 553-557.

Chandra, S., H.K. Buhariwalla, J. Kashiwagi, S. Harikrishna, K.R. Sridevi, L. Krishnamurthy, R. Serraj \& J.H. Crouch, 2004. Identifying QTL-linked markers in marker-deficient crops. In: International Crop Science Congress, 26 September-1 October, Brisbane, Australia.

Charles, M.T., R. Dominique, J. Kumar \& O.P. Dangi, 2002. A preliminary study of the functional properties of chickpea leaves. In: Annual Meeting of the Canadian Society of Food and Nutrition, May 2002, Edmonton, Alberta, Canada.

Cho, S. \& F.J. Muehlbauer, 2004. Genetic effect of differentially regulated fungal response genes on resistance to necrotrophic fungal pathogens in chickpea (Cicer arietinum L.). Physiol Mol Plant Pathol 64: 57-66.

Cho, S., J. Kumar, J.F. Shultz, K. Anupama, F. Tefera \& F.J. Muehlbauer, 2002. Mapping genes for double podding and other morphological traits in chickpea. Euphytica 125: 285292.

Cho, S., W. Chen \& F.J. Muehlbauer, 2004. Pathotype-specific genetic factors in chickpea (Cicer arietinum L.) for quantitative resistance to ascochyta blight. Theor Appl Genet 109: 733-739.

Choumane, W., P. Winter, F. Weigand \& G. Kahl, 2000. Conservation and variability of sequence-tagged microsatellite sites (STMSs) from chickpea (Cicer arietinum L.) within the genus Cicer. Theor Appl Genet 101: 269-278.

Clarke, H. \& K.H.M. Siddique, 2003. Chilling tolerance in chickpea - Novel methods for crop improvement. In: R.N. Sharma, M. Yasin, S.L. Swami, M.A. Khan \& A.J. William (Eds.), International Chickpea Conference, Indira Ghandhi Agricultural University, Raipur, India, pp. 5-12.

Clarke, H. \& K.H.M. Siddique, 2004. Response of chickpea genotypes to low temperature stress during reproductive development. Field Crops Res 90: 323-334.

Clarke, H., T.N. Khan \& K.H.M. Siddique, 2004a. Pollen selection for chilling tolerance at hybridisation leads to improved chickpea cultivars. Euphytica 139: 65-74.

Clarke, H., I. Kuo, J. Kuo \& K.H.M. Siddique, 2004b. Abortion and stages for embryo rescue following wide crosses between chickpea (Cicer arietinum L.) and C. bijugum (K.H. Rech.). In: 5th European Conference on Grain Legumes, AEP, Dijon, France, p. 192.

Cobos, M.J., M. Iruela, J. Rubio, T. Millán, J.I. Cubero \& J. Gil, 2004. Genetic analyses of flowering time in a chickpea interspecific cross (Cicer arietinum L. $\times$ C. reticulatum Lad.). In: 5 th European Conference on Grain Legumes, AEP, Dijon, France, p. 263.

Cobos, M.J., M.J. Fernández, J. Rubio, M. Kharrat, M.T. Moreno, J. Gil \& T. Millán, 2005. A linkage map in chickpea (Cicer arietinum 
L.) in two populations from Kabuli $\times$ Desi crosses: Location of a resistance gene for fusarium wilt race 0. Theor Appl Genet 110: 1347-1353.

Collard, B.C.Y., E.C.K. Pang, P.K. Ades \& P.W.J. Taylor, 2003. Preliminary investigation of QTLs associated with seedling resistance to ascochyta blight from Cicer echinospermum, a wild relative of chickpea, Theor Appl Genet 107: 719-729.

Comai, L., K. Young, J.T. Bradley, S.H. Reynolds, E.A. Green, C.A. Codomo, L.C. Enns, J.E. Johnson, C. Burtner, A.R. Odden \& S. Henikoff, 2004. Efficient discovery of polymorphisms in natural populations by EcoTILLING. Plant J (published online at DOI: 10.1111/j.1365-313X.2003.01999.x)

Cornels, H., Y. Ichinose \& W. Barz, 2000. Characterization of cDNAs encoding two glycine-rich proteins in chickpea (Cicer arietinum L.): Accumulation in response to fungal infection and other stress factors. Plant Sci 154: 83-88.

Croser, J.S., F. Ahmad, H.J. Clarke \& K.H.M. Siddique, 2003a. Utilization of wild Cicer in chickpea improvement-Progress, constraints and prospects. Aust J Agric Res 54: 429-444.

Croser, J.S., H.J. Clarke, K.H.M. Siddique \& T.N. Khan, 2003b. Low temperature stress: Implications for chickpea (Cicer arietinum L.) improvement. Crit Rev Plant Sci 22: 185-219.

Dey, S.K. \& G. Singh, 1993. Resistance to ascochyta blight in chickpea-Genetic basis. Euphytica 68: 147-153.

Díaz-Franco, A. \& P. Pérez-García, 1995. Control químico de la roya y la rabia del garbanzo y su influencia en el rendimiento del grano. Revista Mexicana de Fitopatología 13: 123-125.

Drenkard, E., B.G. Richter, S. Rozen, L.M. Stutius, N.A. Angell, M. Mindrinos, R.J. Cho, P.J. Oefner, R.W. Davis \& F.M. Ausubel, 2000. A simple procedure for the analysis of single nucleotide polymorphisms facilitates map-based cloning in Arabidopsis. Plant Physiol 124: 1483-1492.

Dua, R.P. \& P.C. Sharma, 1995. Salinity tolerance of kabuli and desi chickpea genotypes. Int. Chickpea Pigeonpea Newslett 2: 19-22.

FAOSTAT data, 2005. http://faostat.fao.org/faostat/collections? subset $=$ agriculture. Last updated February 2005.

Flandez-Galvez, H., P.K. Ades, R. Ford, E.C.K. Pang \& P.W.J. Taylor, 2003a. QTL analysis for ascochyta blight resistance in an intraspecific population of chickpea (Cicer arietinum L.). Theor Appl Genet 107: 1257-1265.

Flandez-Galvez, H., R. Ford, E.C.K. Pang \& P.W.J. Taylor, 2003b. An intraspecific linkage map of the chickpea (Cicer arietinum L.) genome based on sequence-tagged microsatellite site and resistance gene analog markers. Theor Appl Genet 106: 1447-1456.

Gaur, P.M. \& A.E. Slinkard, 1990. Genetic control and linkage relations of additional isozyme markers in chickpea. Theor Appl Genet 80: 648-656.

Gil, J. \& J.I. Cubero, 1993. Inheritance of seed coat thickness in chickpea (Cicer arietinum L.) and its evolutionary implications. Plant Breed 111: 257-260.

Gil, J., S. Nadal, D. Luna, M.T. Moreno \& A. de Haro, 1996. Variability of some physico-chemical characters in Desi and Kabuli chickpea types. J Sci Food Agric 71: 179-184.

Gortner, G., M. Nenno, K. Weising, D. Zink, W. Nagl \& G. Kahl, 1998. Chromosomal localization and distribution of simple sequence repeats and the Arabidopsis-type telomere sequence in the genome of Cicer arietinum L. Chromosome Res 6: 97104

Greco, N., 1987. Nematodes and their control in chickpea. In: M.C. Saxena \& K.B. Singh (Eds.), The Chickpea, pp. 271-282. CAB International, UK.
Gumber, R.K., J. Kumar \& M.P. Haware, 1995. Inheritance of resistance to fusarium wilt in chickpea. Plant Breed 114: 277279.

Halila, M.H., N.I. Hadad, B. Sakr \& I. Kusmenoglu, 2000. Regional Reviews-Region 5 Near East. In: R. Knight (Ed.), Linking Research and Marketing Opportunities for Pulses in the 21st Century, pp. 107-114. Kluwer Academic Publishers, Dordrecht, The Netherlands.

Hanselle, T., Y. Ichinose \& W. Barz, 2001. Biochemical and molecular biological studies on infection (Ascochyta rabiei)-induced thaumatin-like proteins from chickpea plants (Cicer arietinum L.). Z Naturforsch [C] 56: 1095-1107.

Hanselle, T., C. Schwenger-Erger \& W. Barz, 1999. Isolation of a full length chalcone synthase cDNA (Accession No. AJ012822) from infected chickpea plants (Cicer arietinum L.). Plant Physiol 120: 934-934.

Haware, M.P., 1998. Diseases of chickpea. In: The Pathology of Food and Pasture Legumes, pp. 473-516. CAB International, UK.

Haware, M.P. \& Y.L. Nene, 1982. Races of Fusarium oxysporum f. sp. ciceris. Plant Dis 66: 809-810.

Hayashi, K., N. Hashimoto, M. Daigen \& I. Ashikawa, 2004. Development of PCR-based SNP markers for rice blast resistance genes at the Piz locus. Theor Appl Genet 108: 1212-1220.

Hein, F., S. Overkamp \& W. Barz, 2000. Cloning and characterization of a full-length cDNA (accession no. AJ250836) encoding phenylalanine ammonia-lyase from chickpea (PGR00-038). Plant Physiol 122: 1458-1458.

Hoehl, B., M. Pfautsch \& W. Barz, 1990. Histology of disease development in resistant and susceptible cultivars of chickpea (Cicer arietinum L.) inoculated with spores of Ascochyta rabiei. J Phytopathol 129: 31-45.

Hong, Z., K. Lakkineni, Z. Zhang \& D.P.S. Verma, 2000. Removal of feedback inhibition of 1 pyrroline-5-carboxylate synthetase (P5CS) results in increased proline accumulation and protection of plants from osmotic stress. Plant Physiol 122: 1129-1136.

Hormaza, J.I. \& M. Herrero, 1996. Male gametophytic selection as a plant breeding tool. Sci Hort 65: 321-333.

Hovav, R., K.C. Upadhyaya, A. Beharav \& S. Abbo, 2003. Major flowering time gene and polygene effects on chickpea seed weight. Plant Breed 122: 539-541.

Hüttel, B., J. Santra, F.J. Muehlbauer \& G. Kahl, 2002. Resistance gene analogues of chickpea (Cicer arietinum L.): Isolation, genetic mapping and association with a Fusarium resistance gene cluster. Theor Appl Genet 105: 479-490.

Hüttel, B., P. Winter, K. Weising, W. Choumane, F. Weigand \& G. Kahl, 1999. Sequence-tagged microsatellite-site markers for chickpea (Cicer arietinum L.). Genome 42: 210-217.

Ibrikci, H., S. Knewtson \& M.A. Grusak, 2003. Chickpea leaves as a vegetable green for humans: Evaluation of mineral composition. J Sci Food Agric 83: 945-950.

Ichinose, Y., K. Tiemann, C. Schwenger-Erger, K. Toyoda, F. Hein, T. Hanselle, H. Cornels \& W. Barz, 2000. Genes expressed in Ascochyta rabiei-inoculated chickpea plants and elicited cell cultures as detected by differential cDNA-hybridization. Z Naturforsch [C] 55: 44-54.

Ichinose, Y., K. Toyoda \& W. Barz, 1999. cDNA cloning and gene expression of three small GTP-binding proteins in defense response of chickpea. Biochem Biophys Acta 1489: 462-466.

ICRISAT (International Crops Research Institute for the Semi-Arid Tropics), 1994. Cold tolerant chickpea varieties ICCV 88503, ICCV 88506, ICCV 88510. Plant Mater Descript 53. 
ICRISAT (International Crops Research Institute for the Semi-Arid Tropics), 2003. In: Archival Report: Global Theme Biotechnology, pp. 31-35. Patancheru, AP, India.

Iruela, M., J. Rubio, J.I. Cubero, J. Gil \& T. Millán, 2002. Phylogenetic analysis in the genus Cicer and cultivated chickpea using RAPD and ISSR markers. Theor Appl Genet 104: 643-651.

Iruela, M., J. Rubio, F. Barro, J.I. Cubero, T. Millán, J. Gil, 2006. Detection of two QTL for resistance to Ascochyta Blight in an intraspecific cross of chickpea (Cicer arietinum L.): Development of SCAR markers associated to resistance. Theor Appl Genet 112: 278-287.

Jamil, F.F., N. Sarwar, M. Sarwar, J.A. Khan, J. Geistlinger \& G. Kahl, 2001. Genetic and pathogenic diversity within Ascochyta rabiei (Pass.) Lab. populations in Pakistan causing blight of chickpea (Cicer arietinum L.). Physiol Mol Plant Pathol 57: 243-254.

Jana, S. \& K.B. Singh, 1993. Evidence on geographical divergence in Kabuli chickpea from germplasm evaluation data. Crop Sci 33: 626-632.

Jayanand, B., G. Sudarsanam, \& K.K. Sharma, 2003. An efficient protocol for the regeneration of whole plants of chickpea (Cicer arietinum $\mathrm{L}$.) by using axillary meristem explants derived from in vitro-germinated seedlings. In Vitro Cell Dev Biol Plant 39: 171-179.

Jayashree, B., H.K. Buhariwalla, S. Shinde, P.V. Kumar \& J.H. Crouch, 2005. A legume genomics resource: The chickpea root expressed sequence tag database and bioinformatics tools. Electron J Biotechnol 8: 128-133.

Jiménez-Díaz, R.M., A.R. Alcalá-Jiménez, A. Hervás \& J.L. Trapero-Casas, 1993. Pathogenic variability and host resistance in the Fusarium oxysporum f. sp. ciceris/C. arietinum pathosystem. In: Proceedings of the 3rd European Seminar on Fusarium Mycotoxins, Taxonomy, Pathogenicity and Host Resistance, Plant Breeding and Acclimatization, Inst, Radzikóv, Poland, pp. 8794.

Jiménez-Gasco, M.M., J.A. Navez-Cortez \& R.M. Jiménez-Díaz, 2004. The Fusarium oxysporum f. sp. ciceris/C. arietinum pathosystem: A case study of the evolution of plant-pathogenic fungi into races and pathotypes. Intern Microbiol 7: 95- 104.

Kaiser, W.J., A.R. Alcalá-Jiménez, A. Hervás-Vargas, J.L. TraperoCasas \& R.M. Jiménez-Díaz, 1994. Screening wild species for resistance to races 0 and 5 of Fusarium oxysporum f. sp. ciceris. Plant Dis 78: 962-967.

Kaiser, W.J., M.D. Ramsay, K.M. Makkouk, T.W. Bretag, N. Acikgoz, J. Kumar \& F.W. Nutter, 2000. Foliar diseases of cool season food legumes and their control. In: R. Knight (Ed.), Linking Research and Marketing Opportunities for Pulses in the 21st Century, pp. 437-455. Kluwer Academic Publishers, Dordrecht, The Netherlands.

Kanazin, V., L.F. Marek \& R.C. Shoemaker, 1996. Resistance gene analogs are conserved and clustered in soybean. Proc Natl Acad Sci USA 93: 11746-11750.

Kasuga, M., Q. Liu, S. Miura, K. Yamaguchi-Shinozaki \& K. Shinozaki, 1999. Improving plant drought, salt, and freezing tolerance by gene transfer of a single stress-inducible transcription factor. Nat Biotechnol 17: 287-291.

Kathiria, K.B., D.R. Nayagapara, M.A. Vaddoria \& V.K. Poshiya, 1997. Screening of chickpea genotypes for salinity tolerance during germination and early seedling growth. Gujarat Agric Univ Res J 22: 28-32.

Kazan, K., F.J. Muehlbauer, N.F. Weeden \& G. Ladizinsky, 1993. Inheritance and linkage relationships of morphological and isozyme loci in chickpea (Cicer arietinum L.). Theor Appl Genet 86: 417426.

Khanna-Chopra, R. \& S.K. Sinha, 1987. Chickpea: Physiological aspects on growth and yield. In: M.C. Saxena \& K.B. Singh (Eds.), The Chickpea, pp. 163-189. CAB International, Wallingford, UK.

Knights, E.J. \& K.H.M. Siddique, 2002. Chickpea status and production constraints in Australia. In: M. Abu Bakr, K.H.M. Siddique \& C. Johansen (Eds.), Integrated Management of Botrytus Grey Mould of Chickpea in Bangladesh and Australia: Summary of Proceedings of a Project Inception Workshop, 1-2 June 2002, Bangladesh Agricultural Research Institute, Joydebpur, Gazipur, Bangladesh, pp. 33-45.

Kraft, J.M., M.P. Haware, H. Halila, M. Sweetingham \& B. Bayaa, 2000. Soilborne diseases and their control. In: R. Knight (Ed.), Linking Research and Marketing Opportunities for Pulses in the 21st Century, pp. 457-466. Kluwer Academic Publishers, Dordrecht, The Netherlands.

Krishnamurthy, L., J. Kashiwagi, H.D. Upadhyaya \& R. Serraj, 2003. Genetic diversity of drought-avoidance root traits in the minicore germplasm collection of chickpea. Int Chickpea Pigeonpea Newslett 10: 21-24.

Kumar, J., 1998. Inheritance of resistance to Fusarium wilt (race 2) in chickpea. Plant Breed 117: 139-142.

Kumar, J. \& S. Abbo, 2001. Genetics of flowering time in chickpea and its bearing on productivity in the semi-arid environments. Adv Agron 72: 107-138.

Kumar, J. \& B.V. Rao, 2001. Registration of "Superearly 96029" Chickpea. Crop Sci 41: 605-606.

Kumar, J., S.C. Sethi, C. Johansen, T.G. Kelley, M.M. Rahman \& H.A. van Rheenen, 1996. The potential of short-duration chickpea varieties. Indian J Dryland Agric Dev 11: 28-32.

Kumar, J. \& H.A. van Rheenen, 2000. A major gene for time of flowering in chickpea. J Hered 91: 67-68.

Ladizinsky, G. \& A. Adler, 1976. The origin of chickpea Cicer arietinum L. Euphytica 25: 211-217.

Leport, L., N.C. Turner, R.J. French, M.D. Barr, R. Duda, S.L. Davies, D. Tennant \& K.H.M. Siddique, 1999. Physiological responses of chickpea genotypes to terminal drought in a Mediterranean type environment. Eur J Agron 11: 279-291.

Lev-Yadun, S., A. Gopher \& S. Abbo, 2000. The cradle of agriculture. Science 288: 1062-1063.

Lichtenzveig, J., C. Scheuring, J. Dodge, S. Abbo \& H.B. Zhang, 2005. Construction of BAC and BIBAC libraries and their applications for generation of SSR markers for genome analysis of chickpea, Cicer arietinum L. Theor Appl Genet 110: 492510.

Maas, E.V. \& G.J. Hoffman, 1977. Crop salt tolerance-Current assessment. J. Irrig Drain Div Proc Am Soc Civil Eng 103: 115-134.

Mackenbrock, U., W. Gunia \& W. Barz, 1993. Accumulation and metabolism of medicarpin and maackiain malonylglucosides in elicited chickpea (Cicer arietinum L.) cell-suspension cultures. J Plant Physiol 142: 385-391.

Maliro, M.F.A., D. McNeil, J. Kollmorgen, C. Pittock \& B. Redden, 2004. Screening chickpea (Cicer arietinum L.) and wild relatives germplasm from diverse country sources for salt tolerance. In: International Crop Science Congress, 26 September-1 October, Brisbane, Australia.

Mallikarjuna, N., 1999. Ovule and embryo culture to obtain hybrids from interspecific incompatible pollinations in chickpea. Euphytica 110: 1-6. 
Matsumura, H., S. Reich, A. Ito, H. Saitoh, S. Kamoun, P. Winter, G. Kahl, M. Reuter, D.H. Kruger \& R. Terauchi, 2003. Gene expression analysis of plant host-pathogen interactions by SuperSAGE. Proc Natl Acad Sci USA 100: 15718-1523.

Mayer, M.S., A. Tullu, C.J. Simon, J. Kumar, W.J. Kaiser, J.M. Kraft \& F.J. Muehlbauer, 1997. Development of a DNA marker for Fusarium wilt resistance in chickpea. Crop Sci 37: 1625-1629.

McIntosh, G.H. \& D.L. Topping, 2000. Food legumes in human nutrition. In: R. Knight (Ed.), Linking Research and Marketing Opportunities for Pulses in the 21st Century, pp. 655-666. Kluwer Academic Publishers, Dordrecht, The Netherlands.

Millán, T., J. Rubio, M. Iruela, K. Daly, J.I. Cubero \& J. Gil, 2003. Markers associated with Ascochyta blight resistance in chickpea an their potential in marker-assisted selection. Field Crops Res 84: 373-384.

Moinuddin, \& R. Khanna-Chopra, 2004. Osmotic adjustment in chickpea in relation to seed yield and yield parameters. Crop Sci 44: 449-455.

Moreno, M.T. \& J.I. Cubero, 1978. Variation in Cicer arietinum L. Euphytica 27: 465-485.

Morgan, J.M., 1984. Osmoregulation and water stress in higher plants. Annu Rev Plant Physiol 35: 299-319.

Morgan, J.M., R.A. Hae \& R.J. Fletcher, 1986. Genetic variation in osmoregulation in bread and durum wheats and its relationships to grain yield in a range of field environments. Aust J Agric Res 37: 449-457.

Morgan, J.M., M.B. Rodriguez \& E.J. Knights, 1991. Adaptation to water deficit in chickpea breeding lines by osmoregulation: Relationship to grain yields in the field. Field Crops Res 27: 6170.

Morjane, H., J. Geistlinger, M. Harrabi, K. Weising \& G. Kahl, 1994. Oligonucleotide fingerprinting detects genetic diversity among Ascochyta rabiei islolates from a single chickpea field in Tunisia. Curr Genet 26: 191-197.

Muehlbauer, F.J. \& K.B. Singh, 1987. Genetics of chickpea. In: M.C. Saxena \& K.B. Singh (Eds.), The Chickpea, pp. 99-125. CAB International, Wallingford, UK.

Musa, A.M., D. Harris, C. Johansen \& J. Kumar, 2001. Short duration chickpea to replace fallow after Aman rice: The role of on-farm seed priming in the high Barind tract of Bangladesh. Exp Agric 37: 509-521.

Nayyer, H., T. Bains \& S. Kumar, 2005. Low temperature induced floral abortion in chickpea: Relationship to abscisic acid and cryoprotectans in reproductive organs: Environmental and Experimental Botany 53: 39-47.

Nene, Y.L. \& M.V. Reddy, 1987. Chickpea Diseases and their control. In: M.C. Saxena \& K.B. Singh (Eds.), The Chickpea, pp. 233270. CAB International, Wallingford. UK.

Nguyen, T.T., P.W.J. Taylor, R.J. Redden \& R. Ford, 2004. Genetic diversity estimates in Cicer using AFLP analysis. Plant Breed 123: $173-179$.

Or, E., R. Hovav \& S. Abbo, 1999. A major gene for flowering time in chickpea. Crop Sci 39: 315-322.

Otte, O., A. Pachten, F. Hein \& W. Barz, 2001. Early elicitor-induced events in chickpea cells: Functional links between oxidative burst, sequential occurrence of extracellular alkalinisation and acidification, $\mathrm{K}^{+} / \mathrm{H}^{+}$exchange and defense-related gene activation. $\mathrm{Z}$ Naturforsch [C] 56: 65-76.

Overkamp, S., F. Hein \& W. Barz, 2000. Cloning and characterization of eight cDNAs from chickpea (Cicer arietinum L.) cell suspension cultures. Plant Sci 155: 101-108.
Pande, S., G.K. Kishore \& J.N. Rao, 2004. Evaluation of chickpea lines to dry root rot caused by Rhizoctonia bataticola. Int Chickpea Pigeonpea Newslett 11: 37-38.

Paran, I. \& R.W. Michelmore, 1993. Development of reliable PCRbased markers linked to downy mildew resistance genes in lettuce. Theor Appl Genet 85: 985-993.

Patankar, A.G., A.M. Harsulkar, A.P. Giri, V.S. Gupta, M.N. Sainani, P.K. Ranjekar \& V.V. Deshpande, 1999. Diversity in inhibitors of trypsin and Helicoverpa armigera gut proteinases in chickpea (Cicer arietinum) and its wild relatives. Theor Appl Genet 99: 719-726.

Peever, T.L., S.S. Salimath, G. Su, W.J. Kaiser \& F.J. Muehlbauer, 2004. Historical and contemporary multilocus population structure of Ascochyta rabiei (teleomorph: Didymella rabiei) in the Pacific Northwest of the United States. Mol Ecol 13: 291309.

Pfaff, T. \& G. Kahl, 2003. Mapping of gene-specific markers on the genetic map of chickpea (Cicer arietinum L.). Mol Genet Genom 269: 243-251.

Prajapati, R.K., R.K. Gangwar \& S.S.L. Srivastava, 2003. Resistance source of chickpea against dry root rot. Farm Sci J 12: 86.

Rajesh, P.N., C. Coyne, K. Meksem, D.K. Sharma, V. Gupta \& F.J. Muehlbauer, 2004. Construction of a HindIII bacterial artificial chromosome library and its use in identification of clones associated with disease resistance in chickpea. Theor Appl Genet 108: 663-669.

Rajesh, P.N., A. Tullu, J. Gil, V.S. Gupta, P.K. Ranjekar \& F.J. Muehlbauer, 2002. Identification of an STMS marker for the double-podding gene in chickpea. Theor Appl Genet 105: 604607.

Rakshit, S., P. Winter, M. Tekeoglu, J. Juarez Muñoz, T. Pfaff, A.M. Benko-Iseppon, F.J. Muehlbauer \& G. Kahl, 2003. DAF marker tightly linked to a major locus for Ascochyta blight resistance in chickpea (Cicer arietinum L.). Euphytica 132: $23-$ 30.

Ratnaparkhe, M.B., D.K. Santra, A. Tullu \& F.J. Muehlbauer, 1998. Inheritance of inter-simple-sequence-repeat polymorphisms and linkage with a fusarium wilt resistance gene in chickpea. Theor Appl Genet 96: 348-353.

Reddy, M.V. \& K.B. Singh, 1984. Evaluation of a world collection of chickpea germplasm accessions for resistance to Ascochyta blight. Plant Dis 68: 900-901.

Reed, W., C. Cardona, S. Sithanantham \& S.S. Lateef, 1987. The chickpea insect pests and their control. In: M.C. Saxena \& K.B. Singh (Eds.), The Chickpea, pp. 283-318. CAB International, Wallingford, UK.

Roberts, E.H., P. Hadley \& R.J. Summerfield, 1985. Effect of temperature and photoperiod on flowering in chickpeas (Cicer arietinum L.). Ann Bot 55: 881-892.

Roetschi, A., A. Si-Ammour, L. Belbahri, F. Mauch \& B. MauchMani, 2001. Characterization of an Arabidopsis-Phytophthora pathosystem: Resistance requires a functional $P A D 2$ gene and is independent of salicylic acid, ethylene and jasmonic acid signalling. Plant J 28: 293-305.

Romo, S., E. Labrador \& B. Dopico, 2001. Water stress-regulated gene expression in Cicer arietinum seedlings and plants. Plant Physiol Biochem 39: 1017-1026.

Rubiales, D.J., I. Moreno, M.T. Moreno \& J.C. Sillero, 2001. Identification of partial resistance to chickpea rust (Uromyces cicerisarietini). In: Proceedings of 4th European Conference on Grain Legumes, AEP, Cracow, Poland, pp. 194-195. 
Rubiales, D., A. Pérez de Luque, D.M. Joel, C. Alcantara \& J.C. Sillero, 2003. Characterization of resistance in chickpea to broomrape (Orobanche crenata). Weed Sci 51: 702-707.

Rubiales, D., J.C. Sillero \& M.T. Moreno, 1999. Resistance to Orobanche crenatam in chickpea. In: J.I. Cubero, M.T. Moreno, D. Rubiales \& J.C. (Eds.), Resistance to Broomrape. The State of the Art, Junta de Andalucía, Sevilla, Spain.

Rubio, J., F. Flores, M.T. Moreno, J.I. Cubero \& J. Gil, 2004. Effects of the erect/bushy habit, single/double pod and late/early flowering genes on yield and seed size and their stability in chickpea. Field Crops Res 90: 255-262.

Rubio, J., E. Moussa, M. Kharrat, M.T. Moreno, T. Millán \& J. Gil, 2003. Two genes and linked RAPD markers involved in resistance to Fusarium oxysporum $\mathrm{f}$. sp. ciceris race 0 in chickpea. Plant Breed 122: 188-191.

Sandhu, J.S. \& S.J. ArasaKesary, 2003. Evaluation of chickpea genotypes for cold tolerance. Int Chickpea Pigeonpea Newslett 10: $9-12$.

Santra, D.K., M. Tekeoglu, M. Ratnaparkhe, W.J. Kaiser \& F.J. Muehlbauer, 2000. Identification and mapping of QTLs conferring resistance to ascochyta blight in chickpea. Crop Sci 40, 16061612.

Savithri, K.S., P.S. Ganapathy \& S.K. Sinha, 1980. Sensitivity to low tolerance in pollen germination and fruit set in Cicer arietinum L. J Exp Bot 31: 475-481.

Saxena, N.P., 1987. Screening for adaptation to drought: Case studies with chickpea and pigeonpea. In: Adaptation of chickpea and pigeonpea to abiotic stresses. Proceedings of Consultant's Workshop, International Crops Research Institute for the Semi-Arid Tropics, Patancheru, AP, India, pp. 63-76.

Saxena, N.P., 2003. Management of drought in chickpea-A holistic approach. In: N.P. Saxena (Ed.), Management of Agricultural Drought-Agronomic and Genetic Options, pp. 103-122. Oxford \& IBH Publising Co. Pvt. Ltd., New Delhi, India.

Saxena, N.P., L. Krishnamurthy \& C. Johansen, 1993. Registration of a drought resistant chickpea germplasm. Crop Sci 33: 1424.

Schadt, E.E., S.A. Monks, T.A. Drake, A.J. Lusis, N. Che, V. Colinayo, T.G. Ruff, S.B. Milligan J.R. Lamb, G. Cavet, P.S. Linsley, M. Mao, R.B. Stoughton \& S.H. Friend, 2003. Genetics of gene expression surveyed in maize, mouse and man. Nature 422: 297-302.

Serraj, R., L. Krishnamurthy \& H.D. Upadhyaya, 2004. Screening chickpea mini-core germplasm for tolerance to soil salinity. Int Chickpea Pigeonpea Newslett 11: 29-32.

Sethi, S.C., D.E. Byth, C.L.L. Gowda \& J.M. Green, 1981. Photoperiodic response and accelerated generation turnover in chickpea. Field Crops Res 4: 215-225.

Shan, F., H. Clarke, G.J. Yang, J. Plummer \& K.H.M. Siddique, 2004. Development of DNA fingerprinting keys for discrimination of Cicer equinospermum (PH Davis) accessions using AFLP markers. Australian Journal of Agricultural Research 55: 947952.

Shan, F., H. Clarke, J. Plummer, G. Yan \& K.H.M. Siddique, 2005. Geographical patterns of genetic variation in the world collections of wild annual Cicer characterised by amplified fragment length polymorphisms. Theor Appl Genet, 110: 381-391.

Sharma, H.C., G. Pampathy, S.K. Lanka \& T.J. Ridsdill-Smith, 2005. Antibiosis mechanism of resistance to legume pod borer, Helicoverpa armigera in annual wild relatives of chickpeas. Euphytica 142: 107-117.
Sharma, K.D., P. Winter, G. Kahl \& F.J. Muehlbauer, 2004. Molecular mapping of Fusarium oxysporum f. sp. ciceris race 3 resistance gene in chickpea. Theor Appl Genet 108: 1243-1248.

Shen, K.A., B.C. Meyers, N. Islam-Faridi, D.M. Stelly \& R.W. Michelmore, 1998. Resistance gene candidates identified using PCR with degenerate oligonucleotide primers map to resistance gene clusters in lettuce. Mol Plant Microbe Interact 11: 815-823.

Siddique, K.H.M., S.P. Loss \& B.D. Thomson, 2003. Cool season grain legumes in dryland Mediterranean environments of Western Australia: Significance of early flowering. In: N.P. Saxena (Ed.), Management of Agricultural Drought, pp. 151-161. Science Publishers, Enfield (NH), USA.

Siddique, K.H.M. \& R.H. Sedgley, 1986. Chickpea (Cicer arietinum L.), a potential grain legume for South-Western Australia: Seasonal growth and yield. Aust J Agric Res 37: 245-261.

Singh, K.B., 1987. Chickpea breeding. In: M.C. Saxena \& K.B. Singh (Eds.), The Chickpea, pp. 127-162. CAB International, Wallingford, UK.

Singh, K.B., 1993. Problems and prospects of stress resistance breeding in chickpea. In: K.B. Singh \& M.C. Saxena (Eds.), Breeding for Stress Tolerance in Cool Season Food Legumes, pp. 17-37. Wiley, Chichester.

Singh, K.B. \& M.V. Reddy, 1983. Inheritance of resistance to ascochyta blight in chickpea. Crop Sci 23: 9-10.

Singh, K.B. \& M.V. Reddy, 1996. Improving chickpea yield by incorporating resistance to ascochyta blight. Theor Appl Genet 92: 509-515.

Singh, K.B., G.C. Hawtin, Y.L. Nene \& M.V. Reddy, 1981. Resistance in chickpeas to Ascochyta rabiei. Plant Dis 65: 586587.

Singh, K.B., L. Holly \& G. Bejiga, 1991. A Catalog of Kabuli Chickpea Germplasm. International Center for Agricultural Research in Dry Areas, Aleppo, Syria.

Singh, K.B., R.S. Malhotra, M.H. Halila, E.J. Knights \& M.M. Verma., 1994. Current status and future strategy in breeding chickpea for resistance to biotic and abiotic stresses. Euphytica, 73: 137-149.

Singh, K.B., R.S. Malhotra \& M.C. Saxena, 1995. Additional sources of tolerance to cold in cultivated and wild Cicer species. Crop Sci 35: 1491-1497.

Singh, K.B., R.S. Malhotra, M.C. Saxena \& G. Bejiga, 1997. Superiority of winter sowing over traditional spring sowing of chickpea in the Mediterranean region. Agron J 89: 112-118.

Singh, K.B., B. Ocampo \& L.D. Robertson, 1998. Diversity for abiotic and biotic stress resistance in the wild annual Cicer species. Genet Resour Crop Evol 45: 9-17.

Singh, K.B., M.V. Reddy \& M.P. Haware., 1992. Breeding for resistance to ascochyta blight in chickpea. In: K.B. Singh \& M.C. Saxena (Eds.), Disease Resistance in Chickpea, pp. 23-54. ICARDA, Aleppo, Syria.

Srinivasan, A., C. Johansen \& N.P. Saxena, 1998. Cold tolerance during early reproductive growth of chickpea (Cicer arietinum L.): Characterisation of stress and genetic variation in pod set. Field Crops Res 57: 181-193.

Srinivasan, A., N.P. Saxena \& C. Johansen, 1999. Cold tolerance during early reproductive growth of chickpea (Cicer arietinum L.): Genetic variation in gamete development and function. Field Crops Res 60: 209-222.

Staginnus, C., B. Hüttel, C. Desel, T. Schmidt \& G. Kahl, 2001. A PCR-based assay to detect $\mathrm{En} / \mathrm{Spm}$-like transposon sequences in plants. Chromosome Res 9: 591-605. 
Staginnus, C., P. Winter, C. Desel, T. Schmidt \& G. Kahl, 1999. Molecular structure and chromosomal localization of major repetitive DNA families in the chickpea (Cicer arietinum L.) genome. Plant Mol Biol 39: 1037-1050

Summerfield, R.J., F.R. Minchin, E.H. Roberts \& P. Hadley, 1981. Adaptation to contrasting aerial environment in chickpea (Cicer arietinum L.). Tropic Agric 58: 97-113.

Tekeoglu, M., D.K. Santra, W.J. Kaiser \& F.J. Muehlbauer, 2000a. Ascochyta blight resistance inheritance in three chickpea recombinant inbred line populations. Crop Sci 40: 1251-1256.

Tekeoglu, M., A. Tullu, W.J. Kaiser \& F.J. Muehlbauer, 2000b. Inheritance and linkage of two genes that confer resistance to fusarium wilt in chickpea. Crop Sci 40: 1247-1251.

Tekeoglu, M., P.N. Rajesh \& F.J. Muehlbauer, 2002. Integration of sequence tagged microsatellite sites to the chickpea genetic map. Theor Appl Genet 105: 847-854.

Tewari, S.K. \& M.P. Pandey, 1986. Genetics of resistance to ascochyta blight in chickpea (Cicer arietinum L.). Euphytica 35: 211-215.

Tiemann, K., D. Inze, M. Van Montagu \& W. Barz, 1991. Pterocarpan phytoalexin biosynthesis in elicitor-challenged chickpea (Cicer arietinum L.) cell cultures. Purification, characterization and cDNA cloning of NADPH: Isoflavone oxidoreductase. Eur J Biochem 15: 751-757.

Tullu, A., F.J. Muehlbauer, C.J. Simon, M.S. Mayer, J. Kumar, W.J. Kaiser \& J.M. Kraft, 1998. Inheritance and linkage of a gene for resistance to race 4 of fusarium wilt and RAPD markers in chickpea. Euphytica 102: 227-232.

Turner, N.C., G.C. Wright, \& K.H.M. Siddique, 2001. Adaptation of grain legumes (pulses) to water-limited environments. Adv Agron 71: 123-231.

Udupa, S.M. \& M. Baum, 2003. Genetic dissection of pathotypespecific resistance to ascochyta blight resistance in chickpea ( $\mathrm{Ci}$ cer arietinum $\mathrm{L}$.) using microsatellite markers. Theor Appl Genet 106: $1196-1202$.

USDA-ARS, Beltville., 2004. Phytochemical Databases: Chickpea. http://www.ars-grin.gov/cgi-bin/duke/ethnobot.pl.

van der Maesen, L.J.G., 1972. Cicer L., a monograph of the genus, with an special reference to the chickpea (Cicer arietinum L.), its ecology and cultivation. In: H. Veenmam \& Q. Zonen (Eds.), 342 pp. Mededlingen Landbouwhogeschool (Communication Agricultural University), Wageningen. van der Maesen, L.J.G. \& R.P.S. Pundir, 1984. Availability and use of wild Cicer germplasm. Plant Genet Resour Newslett 57: $19-24$.

van Rheenen, H.A., M.V. Reddy, J. Kumar \& M.P. Haware, 1992. Breeding for resistance to soil-borne diseases in chickpea. In: K.B. Singh and M.C. Saxena (Eds.), Disease Resistance in Chickpea, pp. 55-70. ICARDA, Aleppo, Syria.

Vlácilová, K., D. Ohri, J. Vrána, J. Cihaliková, M. Kubaláková, G. Kahl \& J. Dolezel, 2002. Development of flow cytogenetics and physical genome mapping in chickpea (Cicer arietinum $\mathrm{L}$.). Chromosome Res 10: 695-706.

Williams, P.C. \& U. Singh, 1987. The Chickpea-Nutritional quality and the evaluation of quality. In: M.C. Saxena \& K.B. Singh (Eds.), The Chickpea, pp. 329-356. CAB International, Wallingford, UK.

Winter, P., T. Pfaff, S.M. Udupa, B. Hüttel, P.C. Sharma, S. Sahim, R. Arreguin-Espinoza, F. Weigand, F.J. Muehlbauer \& G. Kahl, 1999. Characterization and mapping of sequence-tagged microsatellite sites in the chickpea (Cicer arietinum L.) genome. Mol Gen Genet 262: 90-101.

Winter, P., A.-M. Benko-Iseppon, B. Hüttel, M. Ratnaparkhe, A. Tullu, G. Sonnante, T. Pfaff, M. Tekeoglu, D. Santra, V.J. Sant, P.N. Rajesh, G. Kahl \& F.J. Muehlbauer, 2000. A linkage map of the chickpea (Cicer arietinum $L$.) genome based on recombinant inbred lines from a $C$. arietinum $\times$ C. reticulum cross: Localization of resistance genes for fusarium wilt races 4 and 5. Theor Appl Genet 101: 1155-1163.

Winter, P., C. Staginnus, P.C. Sharma \& G. Kahl, 2003. Organisation and genetic mapping of the chickpea genome. In: P.K. Jaiwal \& R.P. Singh (Eds.), Improvement Strategies of Leguminosae Biotechnology, pp. 303-351. Kluwer Academic Publishers, Dordrecht, The Netherlands.

Yang, H., J.G. Boersma, M. You, B.J. Buirchell \& M.W. Sweetingham, 2004. Development and implementation of a sequence-specific PCR marker linked to a gene conferring resistance to anthracnose disease in narrow-leafed lupin (Lupinus angustifolius L.). Mol Breed 14: 145-151.

Yang, H., M.W. Sweetingham, W.A. Cowling \& P.M.C. Smith, 2001. DNA fingerprinting based on microsatellite-anchored fragment length polymorphisms, and isolation of sequence-specific PCR markers in lupin (Lupinus angustifolius L.). Mol Breed 7: 203-209. 